\title{
Myeloid Derived Suppressor Cells Interactions With Natural Killer Cells and Pro-angiogenic Activities: Roles in Tumor Progression
}

\author{
Antonino Bruno ${ }^{1 \dagger}$, Lorenzo Mortara ${ }^{2 \dagger}$, Denisa Baci ${ }^{3}$, Douglas M. Noonan ${ }^{1,2 \ddagger}$ and \\ Adriana Albini ${ }^{1,3 * \neq}$ \\ ${ }^{1}$ Scientific and Technology Pole, IRCCS MultiMedica, Milan, Italy, ${ }^{2}$ Laboratory of Immunology and General Pathology, \\ Department of Biotechnology and Life Sciences, University of Insubria, Varese, Italy, ${ }^{3}$ School of Medicine and Surgery, \\ University of Milano-Bicocca, Monza, Italy
}

OPEN ACCESS

Edited by:

Olivera J. Finn

University of Pittsburgh, United States

Reviewed by:

Emmanuel Katsanis,

University of Arizona, United States

Rolf Kiessling

Karolinska Institute (KI), Sweden

James E. Talmadge,

University of Nebraska Medical

Center, United States

${ }^{*}$ Correspondence:

Adriana Albin

albini.adriana@gmail.com

tThese authors have contributed equally to this work and Co-first

authors

${ }^{\ddagger}$ Co-last authors

Specialty section: This article was submitted to

Molecular Innate Immunity, a section of the journal

Frontiers in Immunology

Received: 13 February 2019 Accepted: 25 March 2019

Published: 18 April 2019

Citation:

Bruno A, Mortara L, Baci D,

Noonan DM and Albini A (2019)

Myeloid Derived Suppressor Cells

Interactions With Natural Killer Cells and Pro-angiogenic Activities: Roles in

Tumor Progression.

Front. Immunol. 10:771.

doi: 10.3389/fimmu.2019.00771
Myeloid-derived suppressor cells (MDSCs) contribute to the induction of an immune suppressive/anergic, tumor permissive environment. MDSCs act as immunosuppression orchestrators also by interacting with several components of both innate and adaptive immunity. Natural killer (NK) cells are innate lymphoid cells functioning as primary effector of immunity, against tumors and virus-infected cells. Apart from the previously described anergy and hypo-functionality of NK cells in different tumors, NK cells in cancer patients show pro-angiogenic phenotype and functions, similar to decidual NK cells. We termed the pro-angiogenic NK cells in the tumor microenvironment "tumor infiltrating NK" (TINKs), and peripheral blood NK cells in cancer patients "tumor associated NK" (TANKs). The contribution of MDSCs in regulating NK cell functions in tumor-bearing host, still represent a poorly explored topic, and even less is known on NK cell regulation of MDSCs. Here, we review whether the crosstalk between MDSCs and NK cells can impact on tumor onset, angiogenesis and progression, focusing on key cellular and molecular interactions. We also propose that the similarity of the properties of tumor associated/tumor infiltrating NK and MDSC with those of decidual NK and decidual MDSCs during pregnancy could hint to a possible onco-fetal origin of these pro-angiogenic leukocytes.

Keywords: myeloid derived suppressor cell (MDSC), natural killer cells (NK cells), angiogenesis, cytokines, tumor microenvironment, decidua

\section{INTRODUCTION}

The tumor microenvironment (TME) shapes the fate of tumor onset and progression, by regulating cell growth, invasiveness, immune escape, dissemination and clinical outcome $(1,2)$. It is now clear that the contribution of tissue-resident immune cells in supporting or limiting tumor growth, metastasis and resistance to therapies has a master role $(2,3)$. The immune cell effector's capabilities of reaching, recognizing, and eliminating the tumor targets is conditioned by other microenvironment cells and determinants, turning the immune system from early strategic line of defense, into a pro-tumor weapon (1-3). TME employs multiple mechanisms to switch off the anti-tumor functions of immune cells: it can destabilize and polarize the innate cell compartment (macrophages, neutrophils and dendritic cells as well as innate lymphoid cells), the adaptive 
immunity ( $\mathrm{T}$ and $\mathrm{B}$ lymphocytes), stromal cells (cancerassociated fibroblasts) or endothelial cells (tumor associated capillary or lymphatic vessels) to favor growth and dissemination (1-4). Plasticity of immune cells, referred as the ability of immune cells to be differentially polarized (for example, acquisition of different or opposite phenotypes and functions) within different (micro/macro) environments (1, 2, 4-6) can represent a friend or a foe. Among the most interesting players in the TME regulation of cancer and metastases are myeloid-derived suppressor cells (MDSCs). MDSCs can directly or indirectly (by interacting with several components of both innate and adaptive immunity) contribute to the induction of an immune suppressive environment $(7,8)$, and angiogenesis (4, 9-11). We will discuss their crosstalk with Natural killer (NK) cells.

NK cells are innate lymphoid cells (ILC) and act as primary effectors of innate immunity, against tumors and virus-infected cells (12). In cancer, NK cells show anergy and hypo-functionality (13-15). NK cells in different tumors have been described by us $(4,16,17)$ and other groups $(18,19)$ to acquire pro-angiogenic phenotype and pro-tumor functions.

MDSCs are recruited and expanded in the TME, in different types of mouse and human cancers (20-24). MDSCs can restrain the $\mathrm{CD}^{+}$cytotoxic $\mathrm{T}$ and NK cells, both of which are anticancer, directly influencing the pro-tumor TME. In this review, we will address MDSC-associated angiogenesis and the crosstalk between MDSCs and NK cells, an under-investigated field, and we will focus on relevant cellular and molecular events orchestrating NK-MDSC interactions within the TME, which can impact on tumor insurgence, progression, and angiogenesis.

\section{NK CELL PHENOTYPE AND FUNCTIONS IN CANCER}

NK cells are cytolytic and cytokine-producing effector innate lymphoid cells (ILC), representing a first line of defense against virally-infected and transformed cells (12). Spits et al. assigned NK cells as a prototypical ILC family member and classified NK cells as ILC1 subtype, as a consequence of their ability to produce IFN $\gamma$, following T-bet and EOMES expression from the ID2 ${ }^{+}$ILC precursor (25). Recently, Vivier et al. put forward that NK cells originate from a separate cell lineage from ILC1. NK cells and ILC1 share the ability to produce IFN $\gamma$, following Tbet expression (26). NK cells and ILC1, however, are functionally different: while NK cells are strongly cytotoxic and release perforin, ILC1s cannot release perforin (26).

The field of NK cell biology has expanded well beyond their cytotoxic functions, underlying new roles related to the vast array of cytokines produced by these cells. NK cells are now known to act in immune responses against bacterial $(27)$ and fungal $(28,29)$ organisms. They have also been shown to play a role in both bone marrow rejection and bone marrow cell engraftment (30). Further NK cell immune regulatory (31) and tissue-regenerative properties (32) have been discovered in viral resistance models.

NK cell cytolytic functions are exerted by perforin and granzyme production and cytokine release. These properties are regulated by a balance between signals from inhibitory receptors (killer Ig-like receptors [KIRs] and the heterodimeric C-type lectin receptor [NKG2A]) as well as activating receptors (the NCRs: NKp46, NKp30, NKp44, and the C-type lectinlike activating immunoreceptor NKG2D), recognizing specific ligands on their cellular targets (12). Peripheral NK cells are predominantly (from 90 to $95 \%$ ) CD56 ${ }^{\mathrm{dim}} \mathrm{CD} 16^{+}$cytotoxic NK cells, that exert their effector functions by perforin/granzyme release and antibody dependent cellular cytotoxicity (ADCC). A minor NK subset, within total circulating NK cells (5-10\%), exhibits the $\mathrm{CD} 56^{\text {bright }} \mathrm{CD} 16^{-}$phenotype and is able to produce high and constant levels of anti-tumor cytokines, such as IFN $\gamma$ and $\mathrm{TNF} \alpha$ (12), CD56 ${ }^{\text {bright }} \mathrm{CD} 16^{-} \mathrm{NK}$ cells are abundant in healthy and neoplastic solid tissues (33).

Pro-angiogenic NK cells have been found in wound healing models (17), a pro-angiogenic NK subset has been also characterized within the developing decidua: decidual (or uterine) NK cells (dNK), that will be discussed later in this review.

Anergic NK cells have been characterized in several tumors, where local immunosuppression resulted in NK cells downregulating NKG2D surface antigen expression, impaired degranulation capabilities, limited abilities to release perforin, granzyme and anti-tumor cytokines (34-38).

We were the first in demonstrating that NK cells in cancer patients (non-small cell lung cancer, NSCLC) $(17,39)$ colorectal cancer (40) and in malignant pleural effusions (16), show a pro-angiogenic phenotype and function, identified as CD56 ${ }^{\text {bright }} \mathrm{CD} 16^{-} \mathrm{VEGF}^{\text {high }} \mathrm{CXCL8}^{+}$IFN $^{\text {low }}$ and share several features with the highly pro-angiogenic dNK cells $(17,39,40)$. In cancer patients, NK cells mimic behavior of decidual NK, they exhibit a dNK-like phenotype, release pro-angiogenic and prometastatic factors and functionally support angiogenesis $(4,16-$ $19,36,39,40)$. We termed the pro-angiogenic NK cells that are in the TME: "tumor infiltrating NK" (TINKs) and peripheral blood pro-angiogenic NK cells in cancer patients "tumor associated NK" (TANKs) (17).

\section{MYELOID-DERIVED SUPPRESSOR CELL PHENOTYPE AND FUNCTIONS IN CANCER}

MDSCs identify a heterogeneous immature and mature cell population generated from common hematopoietic progenitor cell. Two major MDSC subsets have been characterized based on their ability a) to phenotypically resemble polymorphonuclear (PMN) cells, termed PMN-MDSCs b) to resemble monocytes, defined M-MDSCs, for their surface markers. Both cell subsets are endowed with potent inhibitory functions against $\mathrm{CD}^{+}$ cytotoxic $\mathrm{T}$ cells and $\mathrm{NK}$ cells, thus inducing a tolerogenic state and acquiring pro-angiogenic properties (23). In mice, PMN-MDSCs are characterized by $\mathrm{CD}_{11 b^{+}} \mathrm{Ly}_{6 \mathrm{G}}{ }^{+} \mathrm{Ly}_{6 \mathrm{C}}{ }^{\text {lo }}$ while M-MDSCs by $\mathrm{CD}_{11 b^{+} \mathrm{Ly} 6 \mathrm{G}^{-} \mathrm{Ly}^{\mathrm{h}} \mathrm{C}^{\text {hi }} \text { surface }}$ markers. In humans, PMN-MDSCs are identified as $\mathrm{CD}_{11}{ }^{+} \mathrm{CD} 14^{-} \mathrm{CD} 15^{+}$or $\mathrm{CD}^{+} 1 b^{+} \mathrm{CD} 14^{-} \mathrm{CD}_{66}{ }^{+}$, and

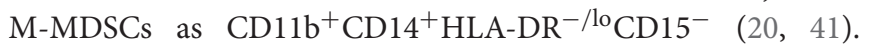
LOX 1 (Lectin type oxidized receptor-1) represents a more recent marker that has been identified on human PMN-MDSCs, however further confirmation is needed (42). 
The immature phenotype of MDSCs is related to the constitutive activation of signal transducer and activator of transcription (STAT)-3, that interferes with the completion of functional cell maturation. The expansion of this subset in tumor patients and tumor-bearing mice is driven also by different factors, such as IRF8, C/EBP $\beta$, Notch, adenosine receptors A2b signaling, and NLRP3 (43). For their immunoregulatory function, the MDSCs requires different pro-inflammatory stimuli, like CSF3, IL-1 $\beta$, IL-6, and prostaglandin E2 (PGE2), through activation of the NF- $\kappa$ B pathway, as well as of STAT1, STAT6, and cyclooxygenase 2 (COX2) signaling (43), as described more in depth later. Immunosuppressive functions exerted by MDSCs are also mediated through the inducible form of nitric oxide synthase (NOS2) that produces nitric oxide (NO), arginase 1 (ARG1), TGF $\beta$, IL-10, COX2, and indoleamine 2,3-dioxygenase (IDO) (44). PGE2 and HMGB1 are also involved in immune suppression (43). In cancer patients, MDSC expansion in the peripheral blood is correlated with poor clinical outcome and with advanced clinical stage (45-47). Tumors growing in mice lead to the expansion and activation of myeloid cells $(48,49)$ with similar activities than the human counterparts, resulting in impairment of anti-tumor T cell responses (50).

It has been shown that MDSCs are able to favor the conversion of naive $\mathrm{CD} 4^{+} \mathrm{T}$ cells into Tregs. Retinoids and MDSC-derived TGF $\beta$ can promote the trans-differentiation of Th17 cells into Foxp $3^{+}$Tregs (51).

\section{MDSC AND NK CELL CROSSTALK}

Immunosuppressive activities by MDSCs have been largely described to be directed toward T cells. Emerging evidence suggests that MDSCs can also interact and regulate the function of other immune cells, including macrophages, DCs and NK cells $(7,8,52-54)$. The contribution of MDSCs in regulating NK cell function in tumor-bearing host, still represent a poorly explored topic. MDSCs produce TGF $\beta$ which we and others have shown to be a master regulator of NK cell functions in tumors $(4,13,17,39,55-58)$ (Figure 1). Studies in the literature showed that co-culture of MDSCs with NK cells resulted in impaired tumor cell cytotoxic activity by NK cells and induction of immunotolerance $(59,60)$. These alterations derived both by MDSC/NK direct interaction (e.g., PDL-1 checkpoint ligand expression and reactive oxygen species production) and via soluble factors (described later in the manuscript). MDSCs have been observed to reduce NK cells tumor suppressive activity (52), and chronic inflammation increases these effects. Several pro-inflammatory cytokines have been reported to orchestrate MDSC/NK crosstalk. Large number of $\mathrm{CD} 11 \mathrm{~b}^{+} \mathrm{Gr}-1^{+}$cells have been found to accumulate in the spleen of tumor-bearing mice and, when adoptively transferred both into tumor-bearing and naïve mice, were able to inhibit NK cell cytotoxicity, by limiting the $\mathrm{NK}$ ability to produce perforin in vivo and in vitro (53). MDSC-mediated NK cell anergy has been associated with the ability of MDSCs to downregulate CD247 expression on the NK cell surface (61). CD247 is a key subunit of natural cytotoxicity receptors (NCRs) NKp46, NKp30, and Fcy RIII
(CD16) (61). MDSCs can inhibit NK cell function by interacting with the NKp30 receptor (62). MDSC/NK cells co-culture results in down-regulation of NKG2D, impaired degranulation capabilities and decreased secretion of IFN $\gamma$ by NK cells (63). The interaction between MDSCs CD11b ${ }^{+} \mathrm{Ly}_{6 \mathrm{C}^{\mathrm{med}}} \mathrm{Ly}_{6 \mathrm{G}}{ }^{+}$and NK cells $\left(\mathrm{CD}^{-} \mathrm{NK} 1.1^{+}\right)$in the murine pre-metastatic niche has been reported to be critical for metastases establishment (64). The cytotoxicity of NK cells in breast cancer is significantly decreased in the presence of MDSCs, resulting in increased metastatic potential (64). MDSCs inhibit the anti-tumor reactivity of NK cells, promote angiogenesis (65), establish pre-metastatic niches (66), and recruit other immunosuppressive cells (67). MDSC accumulation has been demonstrated to occur, following surgery both in human and mice, which results in dysfunctional NK cells $(68-70)$.

The immune suppressive TME leads to phenotype and functional alterations of several players, including NK cells and MDSCs. Most of soluble molecules within the TME include factors able in shaping $\mathrm{NK}$ cell and MDSC response and several of them are shared interactors regulating MDSC/NK crosstalk. Here, we discussed selected soluble factors modulating MDSC/NK cell crosstalk within the TME, as potential candidates to target aberrant phenotype/function endowed with pro-tumor and pro-angiogenic activities.

\section{CYTOKINES AND OTHER MEDIATORS IN NK AND MDSC REGULATION}

The STAT family are transcription factors that are activated in response to growth factors and cytokines and mediate downstream signaling (71-74). STATs are dysregulated in a broad range of cancer types. STATs have been shown to play diverse roles in innate and adaptive immune cells in the TME (7577). While STAT2 and STAT4 promote the anti-tumor immune response, STAT3 and STAT6 mediate immunosuppression in the TME, and STAT1 and STAT5 have been implicated in both activation and suppression of the anti-tumor immune response (78). STAT3 activation in an immature MDSC subset, has been found to be crucial for NF- $\mathrm{B}$ activation, resulting in enhanced release of IDO, that limit NK cell proliferation, activation and effector functions (79) (Figure 2). Several studies demonstrated a link between STAT3 blockade, TGF $\beta$ inhibition and increased tumor surveillance by NK cells $(80,81)$. Peripheral and tumor-associated NK cells from STAT3-targeted tumorbearing mice expressed elevated levels of NK activation markers NKG2D, CD69, Fas ligand (FasL) granzyme B, perforin, and IFN $\gamma$, resulting in reduced tumor growth and enhanced survival $(80,81)$.

IL-2 induced activation of STAT5 leads to NK cell production of perforin, granzyme and IFN $\gamma$ (82). JAK3-mediated activation of the transcription factor STAT5 is critical in IL-2-stimulated NK cells in vitro and Jak3 inhibition has been found in NK cells co-cultured with MDSC isolated from the spleen of tumorbearing mice associated with reduced STAT5 in NK cells (62). STAT3/STAT5 activation was observed by us in TANKs from colon cancer patients (40). We have shown that treatment with 


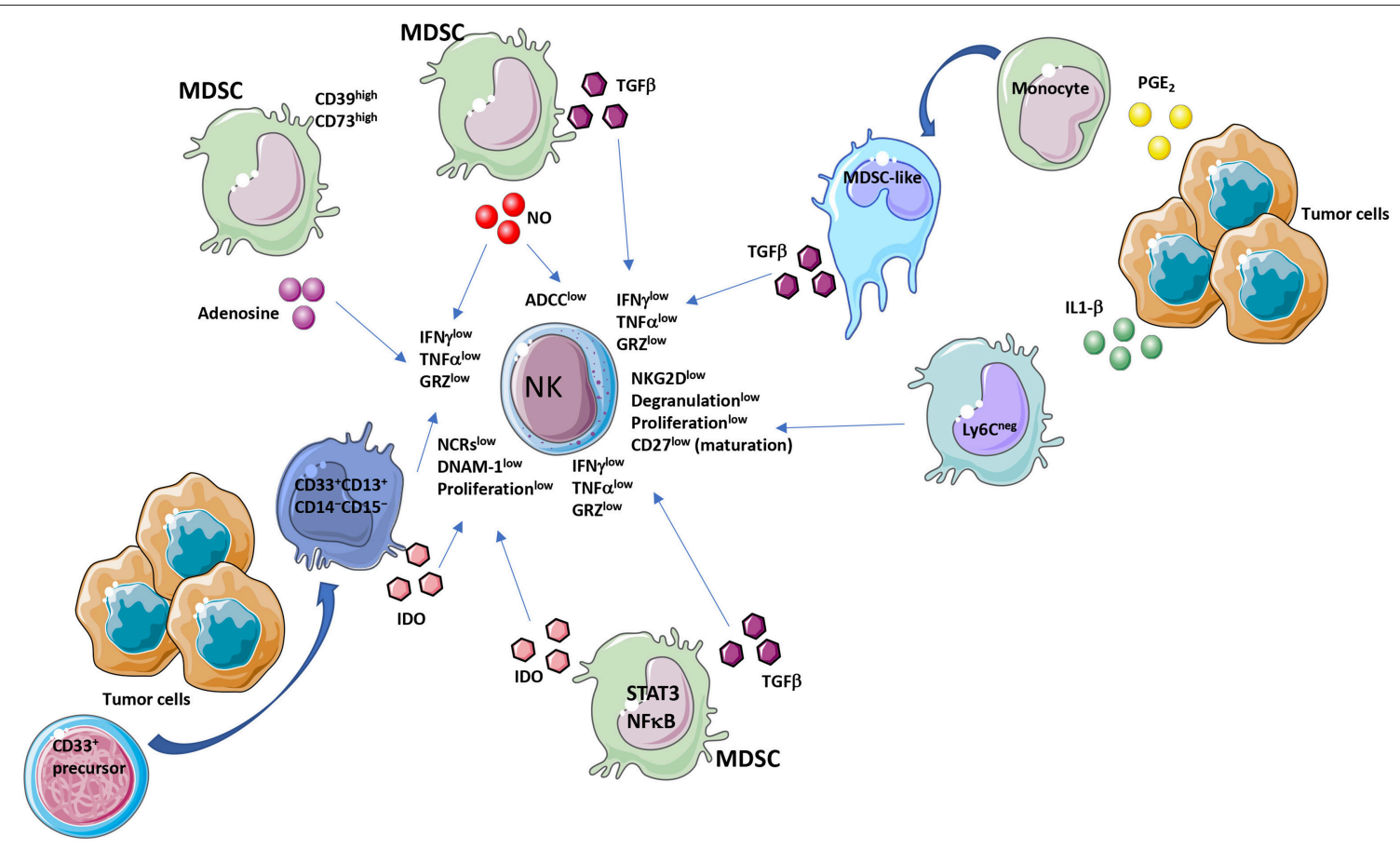

FIGURE 1 | MDSC and NK crosstalk within the tumor microenvironment (TME). Immunosuppressive activities of MDSCs on NK cells act by diverse molecular and cellular mediators. MDSC affect NK cell functionality by several major released factors, among which TGF $\beta$. TGF $\beta$ is produced by MDSC or by MDSC-like cells, originated from PGE2 exposed monocytes. Another mediator is IDO produced directly from MDSCs or from a CD33 ${ }^{+} \mathrm{CD}_{13}{ }^{+} \mathrm{CD} 14^{-} \mathrm{CD} 15^{-}$subset, derived from $\mathrm{CD}_{3}{ }^{+}$precursors. Adenosine from CD39 ${ }^{\text {high }} \mathrm{CD} 73^{\text {high }} \mathrm{MDSC}$ is a further major NK suppressive factor. MDSC effectors decrease NKG2D, NCRs, IFN $\gamma, \mathrm{TNF} \alpha$, perforin, granzyme levels and ADCC in NK cells.

pimozide, a STAT5 inhibitor, reduced endothelial cell capability to form capillary-like networks, inhibiting VEGF and angiogenin production without affecting the levels of TIMP1, TIMP2, and MMP9, indicating that STAT5 is involved in cytokine modulation but not invasion-associated molecules in colon cancer TANKs (40).

MDSCs release TGF $\beta$ in the TME (23, 48, 83) (Figure 1). TGF $\beta$ exerts anti-tumorigenic effects at early stages, while during tumor progression it acts as crucial orchestrator of angiogenesis, induction of immunosuppression and metastases (84-86). In a murine model of liver cancer, tumor derived MDSCs have been reported to induce NK cell anergy, exhibited as reduced NKG2D expression, degranulation capability, cytotoxicity and IFN $\gamma$ release in vitro and in vivo, through membrane-bound TGF $\beta_{1}$ (59). Blocking of membrane-bound TGF $\beta$ on MDSCs was able to subvert the inhibitory effects on NK cells, demonstrating that MDSC/NK cell-cell contact is necessary to induce MDSCmediated NK cell anergy.

Elkabets et al. have identified a novel subset of MDSC induced by IL-1 $\beta$, which lack Ly6C expression (52) (Figure 1). This subset was present at low frequency in tumor-bearing mice in the absence of IL- $1 \beta$-induced inflammation; while under inflammatory conditions Ly6 $\mathrm{C}^{\text {neg }}$ MDSC were predominant. Ly6C $^{\text {neg }}$ MDSC impaired NK cell development and functions in vitro and in vivo (52) by reduction of NKG2D activating receptor (Figure 1). Another recently identified NK check-point is the IL-1R8 receptor (also known as SIGIRR, or TIR8), which is expressed on human and murine NK cells (87). IL-33, an "alarmin" molecule released upon tissue stress or damage by endothelial and epithelial cells $(88,89)$, is an IL-1 family member which binds to the ST2 receptor, expressed on immune cells. In murine models, IL-33, depending on the TME, can recruit immune cells with pro-tumor effects, including MDSCs, TAMs, and Tregs, or it can prevent tumor development by stimulating activation and migration of $\mathrm{NK}$ and $\mathrm{CD}^{+} \mathrm{T}$ cells $(88,89)$. In humans, IL-33 is associated with poor prognosis in glioma, breast and ovarian cancers, clear-cell renal and hepatocellular carcinoma, while it is correlated with good prognosis in colorectal cancer and lung adenocarcinoma $(88,89)$.

Nitric Oxide (NO) molecule is a multifunctional gaseous transmitter, playing a key role in inflammation. Paradoxical effects of NO have been documented in cancer, since its anti- or pro-tumor activities are finely tuned by timing, location, and concentration $(90,91)$. NO production has been largely demonstrated as a key mechanism in MDSC-mediated immunosuppression $(90,92)$ (Figure 1). Some studies showed that autocrine production of $\mathrm{NO}$ by NK cells results in positive effect on NK cell function, and that human NK cells can express endothelial nitric oxide synthase (eNOS) but not inducible nitric oxide synthase (iNOS) $(93,94)$. In contrast, Stiff et al. recently demonstrated that NO production by MDSCs limits NK cell cytotoxicity by impairing Fc receptor-mediated NK cell function, 


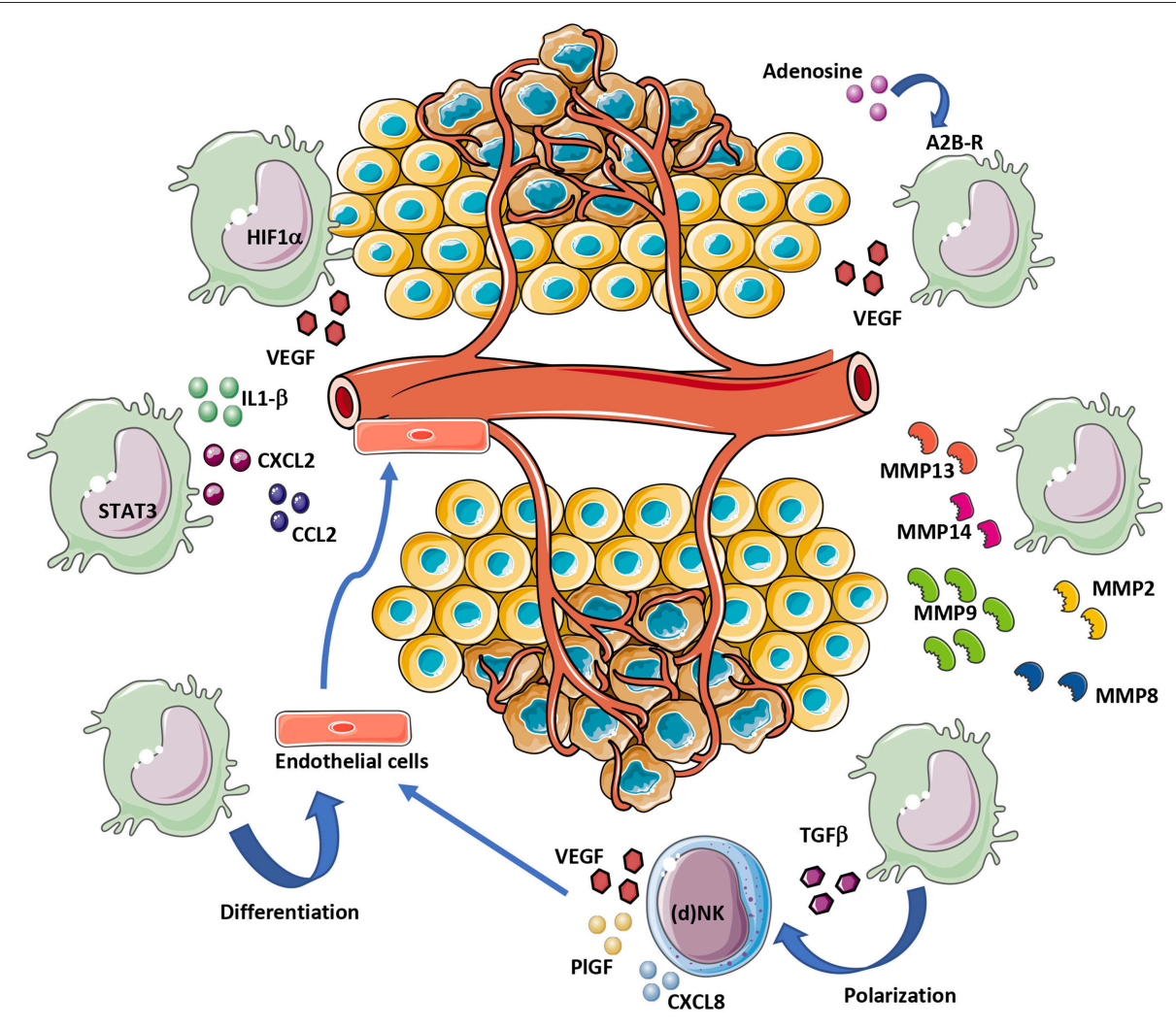

FIGURE 2 | MDSC contribution to tumor angiogenesis. MDSCs can support angiogenesis by different mechanisms. Hypoxia within the TME induce VEGF release directly from MDSCs or indirectly following exposure of MDSCs to TGF $\beta$ and adenosine. STAT3 activation in MDSCs also support angiogenesis, via IL1- $\beta$, CXCL2, and CCL2 secretion. MDSCs contribute to tumor angiogenesis by ECM remodeling via MMP-2/8/9/13/14 release. Finally, given their cell plasticity, MDSCs can transdifferentiate into endothelial-like cells.

resulting in altered ADCC (92). They also showed that co-culture of MDSCs with NK cells results in inhibited secretion of IFN $\gamma$ and TNF $\alpha$ by NK cells (Figure 2).

Prostaglandin $\mathrm{E}_{2}\left(\mathrm{PGE}_{2}\right)$ is a prostanoid molecule generated by the COX2 inflammatory cascade that have been largely reported to be associated with pro-tumor activities, ranging from induction of tumor cell growth, enhancement of tumor cell migration, invasion, induction of immunosuppression and angiogenesis (95-97). Exposure of monocytes to $\mathrm{PGE}_{2}$ results in the generation of a MDSC-like phenotype, together with induction of intracellular signaling pattern, which enables them to suppress NK cell anti-tumor activity in a TGF $\beta$ dependent manner (98) (Figure 1). The same effects were observed in NK cells co-culture with freshly isolated CD14 ${ }^{+} \mathrm{HLA}-\mathrm{DR}{ }^{\text {low } /-} \mathrm{M}$ MDSC from patients with melanoma (98). Selective inhibition of COX limited the accumulation of $\mathrm{CD}_{11} \mathrm{~b}^{+} \mathrm{Gr}^{+}$MDSCs in the spleen, providing improved in vivo clearance of NK-cell sensitive YAC-1 cells in murine 4T-1 tumor cells (98). In a mouse model of acute inflammation obtained using zymosan, infiltration of NK cells was an early event with production of IFN $\gamma$, which upregulated microsomal PGE synthase-1 (mPGES-1) and COX1 , resulting in sustained $\mathrm{PGE}_{2}$ biosynthesis (99). $\mathrm{PGE}_{2}$ inhibited lymphocyte function and generated myeloid-derived suppressor cells (99).
Indoleamine 2,3-dioxygenase (IDO) is an intracellular monomeric, heme-containing enzyme able to regulate the tryptophan catabolism into kynurenine $(100,101)$. Kynurenine production will result in inhibition of proliferation and effector functions in NK and T cells $(78,102-105)$. MDSCs have been reported as an IDO producer cells within the TME, in both humans and mice. An immature subset of MDSCs, characterized as $\mathrm{CD} 33^{+} \mathrm{CD} 13^{+} \mathrm{CD} 14^{-} \mathrm{CD} 15^{-}$, has been identified $(79,106)$. This subset has been found to be induced from $\mathrm{CD}_{3}{ }^{+}$ precursor cells that, following co-culture with the human breast cancer cell line MDA-MB-23, result in elevated production of IDO (Figure 1). IDO synthesized by MDSCs blocked NK cell development, proliferation, and activation, resulting in dramatically decreased expression of NCR, NKG2D, and DNAM-1 and by reducing IFN $\gamma$ release $(107,108)$ (Figure 1).

As a consequence of hypoxia and inflammation, high levels of adenosine, an immunosuppressive molecule, are released within the TME, (109). Adenosine acts by engaging four subtypes of P1 purinergic or adenosine receptors, $\mathrm{A} 1, \mathrm{~A} 2 \mathrm{~A}, \mathrm{~A} 2 \mathrm{~B}, \mathrm{~A} 3, \mathrm{~A} 2 \mathrm{AR}$, and $\mathrm{A} 2 \mathrm{BR}$, that have been found to be expressed in immune cells $(109,110)$. A1, A2A, A2B, A3, A2AR, and A2BR mRNA levels dramatically increase in inflammatory cells within the TME (110). Adenosine/adenosine receptor interactions result in subverted immune cell activities, leading to immunosuppression 
and angiogenesis driven by inflammatory cells (109). The enzyme CD39 converts extracellular ATP to AMP, and CD73 converts AMP to adenosine. MDSCs are able to express high levels of CD39/CD73 in tumor lesions, resulting in higher secretion of adenosine $(111,112)$ (Figure 2). Adenosine inhibits NK cell anti-tumor activities by blocking granzyme exocytosis, impairing perforin and Fas ligand-mediated cytotoxic activity and limiting IFN $\gamma / \mathrm{TNF} \alpha$ release (113) (Figure 1). CD56 ${ }^{\text {bright }} \mathrm{CD} 16^{-} \mathrm{NK}$ cells produce adenosine through a CD38-mediated pathway, another mechanism to generate extracellular AMP (114). Finally, it has been demonstrated that adenosine signaling is involved in limiting NK cell maturation and that engagement of A2A adenosine receptor (A2AR) acts as a checkpoint in this process (115).

\section{DECIDUAL NK AND MDSCs DURING PREGNANCY: A POSSIBLE ONCO-FETAL ORIGIN OF PRO-ANGIOGENIC LEUKOCYTES}

During pregnancy, profound and complex changes occur in the female organism in order to regulate and control the immune response to the fetus, thus conferring tolerance from rejection. This level of regulation in maternal immune system is achieved through coordination and crosstalk of different immune cells, including NK cells, MDSCs, DCs, and Tregs. The dNK cells represent an NK cell subset that has been characterized within the developing decidua and constitutes approximately $70 \%$ of the lymphoid cells in the decidua $(116,117)$. dNK cells have a CD56 ${ }^{\text {superbright }} \mathrm{CD} 16^{-}$VEGF $^{\text {high }}$ PlGF $^{\text {high }}$ phenotype $(58,116$, $117)$ and are endowed with pro-angiogenic activities, necessary for spiral artery formation. dNK are associated with induction of a tolerogenic environment to host the fetus and permit the correct embryo implantation, both in humans and mice (116, 117). Low levels of dNK cells is associated with miscarriage $(17,116)$. We have described the expression of angiogenin, in NK from patients with colon cancer (40). Angiogenin was previously reported to be secreted by dNK $(118,119)$. The TANKs in patients with colon cancer also express MMP2, MMP9, and TIMP, as shared features with dNK cells $(116,120,121)$ which could be relevant to the invasive capabilities and proangiogenic functions of colorectal cancer-NK cells (40). Maternal dNK KIR and HLAC interaction has an effect on birth weight (122), particularly the paternal HLA-C, and correlates with pre-eclampsia and fetal growth restriction $(123,124)$.

In healthy pregnant women, significant increase in numbers of PMN-MDSCs are detected as compared to non-pregnant controls (125). The raise of PMN-MDSCs mainly occurs in the first trimester (126). Accordingly, reduced PMN-MDSCs are associated with miscarriage (126). The mechanisms involved in this regulation could be related to the release of ARG1, NO, IDO, and indirectly by recruitment and activation of dNK cells and Tregs $(127,128)$. Serum levels of ARG1, an important effector molecule for PMN-MDSC are significantly reduced in pre-eclampsia patients as compared to healthy pregnant women
(129). Behavior of immune cells in tumors might resemble the one in the decidua (4).

\section{MDSC AND TUMOR ANGIOGENESIS}

MDSCs promote tumor progression also through non-immune activities, by stimulating pre-metastatic niche formation, invasion $(130,131)$ and inducing pro-tumor angiogenesis (132) (Figure 2). In the TME, MDSCs, by production of VEGF, FGF2, Bv8, and matrix metalloprotease (MMP) 9 (MMP9), can trigger and sustain tumor angiogenesis $(44,133)$ (Figure 3). Co-injection of murine tumors with $\mathrm{CD}_{11 b^{+}} \mathrm{Gr}^{+}$MDSCs increased intra-tumor vascular density, reduced necrosis, and augmented tumor growth $(133,134)$. CD11 $\mathrm{b}^{+} \mathrm{Gr} 1^{+}$MDSCs cells directly contribute to tumor angiogenesis by producing MMP9 or acquiring endothelial cell properties in TME (133). MDSCs may directly take part in the formation of tumor vasculature by being incorporated into the vessel wall $(133,135)$ (Figure 3). Several studies have linked MDSC accumulation with an increase in intra-tumor VEGF concentration during disease progression (136). Approaches aiming at reducing levels of circulating MDSCs or in the tumor milieu were associated with decreased angiogenesis and delayed tumor growth $(132,137)$.

MDSCs can boost angiogenesis and stimulate tumor neovasculature by producing high levels of MMPs (Figure 2), including MMP2, MMP8, MMP9, MMP13, and MMP14 $(130,133,138)$. MDSCs from MMP9-knockout mice have a significant reduction in their tumor promoting activity (133). Previous research has indicated that MDSCs with high levels of MMP9, trigger VEGF function by raising its bioavailability (139). In a mouse melanoma model, MDSCs contributed to A2B adenosine receptor-induced VEGF production, increased vessel density and angiogenesis $(140,141)$.

VEGF in turn stimulates MDSC recruitment, creating a positive feedforward loop. Promoting immunosuppression and angiogenesis $(142,143)$. MDSCs stimulated by VEGF had stronger immunosuppressive properties than non-stimulated MDSCs (143). VEGF-induced MDSCs stimulate the expansion of other immunosuppressive cells, including $\mathrm{FOXP}^{+}$Tregs, through a TGF $\beta$-dependent and/or independent pathway (143145). The relationship between development of resistance to antiangiogenic therapy with significant MDSC infiltration have been widely demonstrated in several studies (146-148). In agreement with these findings, MDSCs ablation has been reported to have synergistic effects with anti-VEGF/VEGFR treatment in refractory tumors $(130,143)$. It is now widely accepted that MDSCs interfere with the efficacy of VEGF-targeted therapy, either by secreting large quantities of VEGF that overcome VEGF inhibition, or by activating VEGF-independent pro-angiogenic signaling pathways (149).

The expression of VEGF, MDSCs can modify the TME in a pro-angiogenic manner through the production of several other angiogenic factors and also chemokines which can further enhance MDSCs accumulation within tumors, creating a vicious circle. CCL2, CXCL8, CXCL2, IL-1 $\beta$, angiopoietin 1 and 2, and GM-CSF have been shown to contribute to MDSC-mediated 


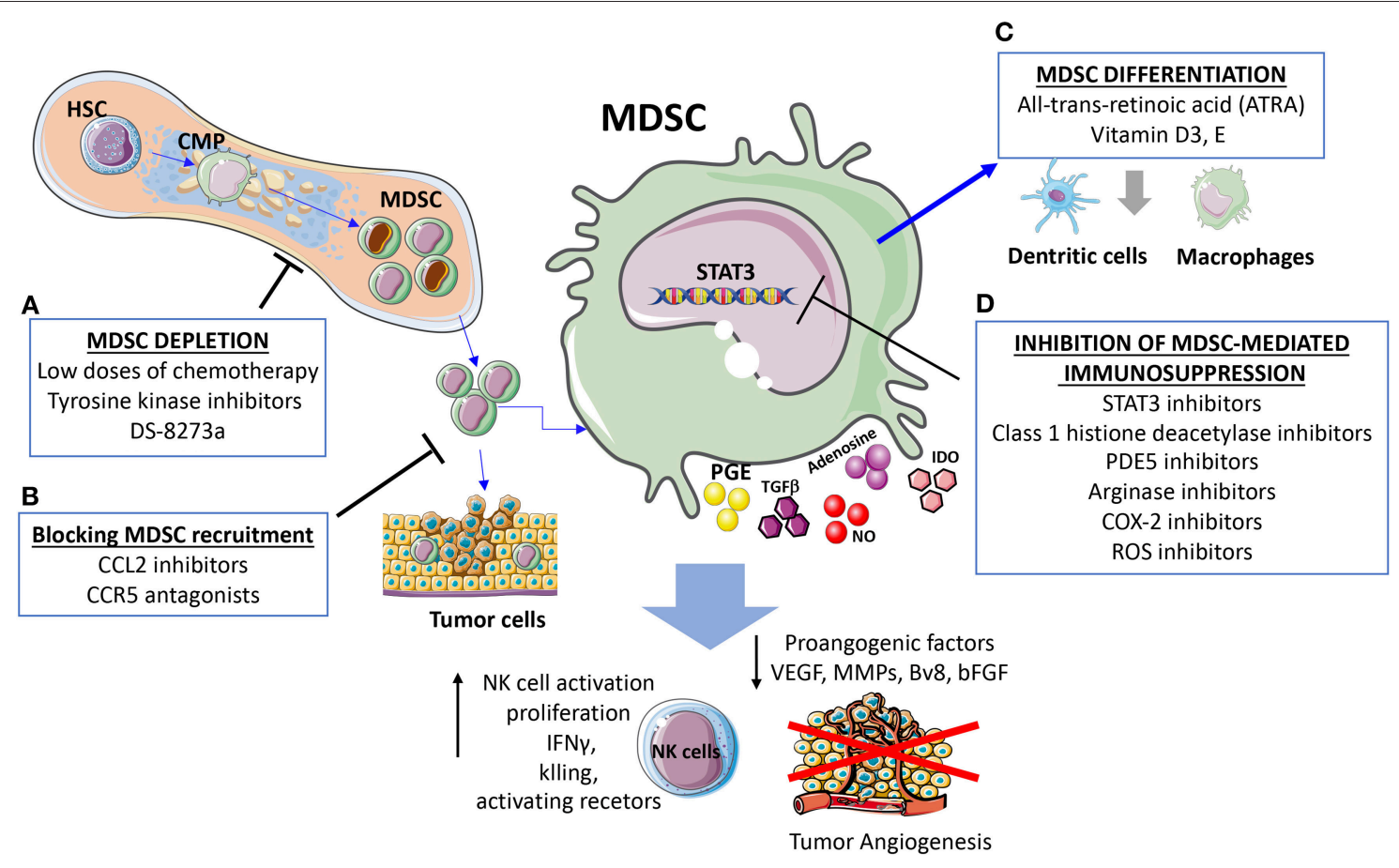

FIGURE 3 | Strategies for targeting MDSC and cross-talk with NK. The presented strategies act simultaneously on MDSC and MDSC-released factors dampening NK cell immunosuppression and induction of angiogenesis. (A) MDSC depletion can be induced using low doses of chemotherapy, tyrosine kinase inhibitors, the anti-DR5 monoclonal antibody DS-8273a. (B) Strategies blocking MDSC recruitments by CCL2 inhibitors and CCR5 antagonists. (C) Differentiation of MDSC into non-immunosuppressive cells induced by all-trans-retinoic acid (ATRA), Vitamin D3, and Vitamin E. (D) Inhibition of MDSC immunosuppression can be induced by STAT3 inhibitors, reduction of immunosuppressive agents such as Arginase and ROS, along with attenuation of the inflammatory state.

angiogenesis and require STAT3 for their expression $(4,150-$ 152) (Figure 2). Anti-CCL2 treatment decrease PMN-MDSC and M-MDSC and reduce endothelial cell migration (150, 153, 154). MDSCs promote angiogenesis also via expression of a prokineticin 2, known as Bv8, which plays an important role in myeloid cell-mediated tumor angiogenesis (155). A refractory behavior to anti-VEGF therapy was associated with high number of $\mathrm{CD} 1 \mathrm{~b}^{+} \mathrm{Gr} 1^{+}$cells expressing Bv8 in peripheral blood and tumor (156). Thus, it has been suggested that combination of anti-Bv8 antibodies and anti-VEGF may better inhibit angiogenesis and control the tumor growth in antiVEGF refractory tumors $(156,157)$. A close expression among molecules associated with angiogenesis: p-STAT3, VEGFA, CK2, and the MDSCs marker CD11b was found in head and neck squamous cell carcinoma (HNSCC) patients (158). Inhibition of JAK2/STAT3 in HNSCC transgenic mouse model reduced MDSC number and suppressed angiogenesis by decreasing VEGFA and hypoxia inducible factor (HIF-1 $\alpha$ ) both in vitro and vivo (158) (Figure 2).

Hypoxia, which is a feature of tumor bearing TME, has a crucial role in stimulating HIF- $1 \alpha$ mediated signaling. HIF1 and/or HIF-2 create a proangiogenic TME by inducing the expression of proangiogenic factors (VEGF, ANG-2, PlGF, bFGF, and semaphorin 4D). It was shown that in myeloid cells, HIF1 activation promotes angiogenesis through VEGF and S100A8 (159) and lead to accumulation of MDSCs positive for the expression of CX3CR1, a CCL26 receptor, in hypoxic tumor regions $(111,160)$ (Figure 2).

ROS (radical oxygen species) also play an important role in the expansion of MDSCs and augmented levels of these molecules have been shown to stimulate the expression of VEGF receptors on MDSCs and their recruitment in the TME $(142,161)$.

\section{STRATEGIES TO TARGET MDSCs AND INTERFERE WITH NK CROSSTALK}

The main strategies to target MDSC and consequently their crosstalk with NK cells include: (i) regulation of myelopoiesis and MDSC depletion (tyrosine kinase inhibitors, cytotoxic agents), (ii) enhancement of MDSC differentiation (ATRA, Vitamin A, D3), (iii) inhibition of MDSC recruitment at the site of tumor (CCR5 antagonist, CCL2 inhibitor) $(132,162)$, (iv) inhibition of MDSC-mediated immunosuppression (STAT3 inhibitors, PDE5, histone deacetylase, NO inhibitors, Arginase inhibitors, ROS inhibitors, COX-2 inhibitors, phenformin, metformin, Polyinosinic-polycytidylic acid) (Figure 3). Here, we will briefly discuss strategies to target MDSC immunosuppression and the effects on angiogenesis and NK cell.

Recent work has provided evidence that relatively low doses of chemotherapy induce MDSC exhaustion $(22,163)$. Gemcitabine (164), Lurbinectedin (PM01183) (165) 5-azacytidine (166), 
docetaxel (167), paclitaxel (168), 5-Fluorouracil (169), and doxorubicin (170) exert beneficial effects by reducing MDSC frequencies, increasing responsiveness to immune therapy and enhancing the antitumor activity of activated NK cells (171-174). Similarly, tyrosine kinase inhibitors such as Axitinib, sunitinib, and brutinib, directly target VEGF and/or c-KIT signaling, interfering with tumor-driven expansion MDSC factors such as M-CSF and STAT3 (175-181). In addition to angiogenesis inhibition, sunitinib treatment upregulates NKG2DLs and induces higher cytotoxic sensitivity of tumor cells to NK cells (182-184).

Several studies reported that vitamins D3, A, and E decrease levels of immature MDSC leading to improved anti-tumor activity in the context of immunotherapeutic interventions $(185,186)$. Vitamin D insufficient and deficient patients had lower NK-mediated cytotoxicity (187), whereas vitamin D receptor (VDR) agonist inhibited selectively ocular hyaloid vasculature angiogenesis in zebrafish models (188). Vitamin E enhance immune responses via reducing ROS levels and inhibition of $\mathrm{PGE}_{2}, \mathrm{COX} 2$, activity mediated through decreasing NO production (189). MDSCs impair NK cell function via production of NO (92), thus, its inhibition offers a strategy for targeting MDSC-NK crosstalk. Promising results on reducing MDSC frequency or increasing their differentiation, were obtained in clinical trials using vitamin A metabolite, all -trans-retinoic acid (ATRA), tested alone (190-192) or in combination with IL-2 administration (191) or with a DC vaccine against p53 (193). In preclinical breast cancer models, ATRA improved antiangiogenic therapies by reverting the anti-VEGFR2-induced accumulation of intratumoral MDSCs, decreased hypoxia, and interfered with the disorganization of tumor microvessels (194). Similarly, it was shown that ATRA, suppresses the angiopoietin-Tie2 pathway, inhibits angiogenesis and progression of esophageal squamous xenograft tumors (195). ATRA increased the expression of MICA and MICB in tumor cells, promoting NK cell activation $(175,196)$, although other studies reported contrasting effects $(197,198)$.

Blockade of MDSC recruitment at the tumor site inhibits the establishment of an immunosuppressive pre-metastatic niche, via MDSC suppression of NK cells (64). Blocking CCR5/CCR5 ligand interaction by using fusion protein mCCR5-Ig-neutralizing CCR5 ligands, reduced migration, and immunosuppressive potential of MDSCs in the TME and significantly improved survival of tumor-bearing mice (199). In addition, blocking CCL2, which is produced by MDSCs, using specific antibodies can reduce angiogenesis by blocking endothelial cell migration (153).

STAT3 pharmacological inhibition (by peptidomimetics, small molecule inhibitors, platinum agents, curcumin, JAK inhibitors, AG490, Cucurbitacin B) simultaneously blocks angiogenesis and accumulation/suppressive function of MDSC, neutralizing the induction of a tolerogenic/tumor permissive TME, without MDSC depletion (158, 200-202).

JAK/STAT3 inhibitors suppress angiogenesis and reduce MDSCs in the TME through VEGFA and CK2 inhibition (158). Several studies demonstrated a link between STAT3 blockade, TGF $\beta$ inhibition and increased tumor surveillance by NK cells
$(80,81)$. Peripheral and tumor-associated NK cells in STAT3targeted tumor-bearing mice, exhibit higher expression of the NK activation markers NKG2D, CD69, Fas ligand (FasL), granzyme $\mathrm{B}$, perforin, and IFN $\gamma$, resulting in reduced tumor growth and enhanced survival $(80,81)$. Given the STAT3 inhibitors side effects, a STAT3siRNA or decoy STAT3 oligonucleotide inhibitors, such as AZD9150 have been recently developed and combined with immune checkpoint inhibitors, in phase I/II clinical trials (203-205). In similar approach, STAT3 siRNA or decoy oligonucleotides, coupled to $\mathrm{CpG}$ oligonucleotides, have been employed to ensure a selective delivery of the drugs to TLR9-expressing myeloid cells (in particular, PMNMDSC), displaying a decreased immunosuppressive activity (203). Therefore, STAT3 inhibitors provide a potential strategy to reduce immunosuppression activate NK cells and reduce angiogenesis (4).

Class I histone deacetylase inhibitor, entinostat, has been reported to inhibit the immunosuppressive function of MDSC by reducing ARG1, iNOS, and COX2 levels in both $\mathrm{M}$ - and PMN-MDSC subsets $(206,207)$. Vorinostat and entinostat significantly enhanced the expression of multiple NK ligands and death receptors, resulting in enhanced NK cell-mediated cytotoxicity (208).

Several clinical and preclinical mouse model studies, employing PDE-5 inhibitors, such as sildenafil and tadalafil, have demonstrated decreased MDSC accumulation and their immunosuppressive pattern functions by inhibiting iNOS, ARG1, IL4Ra, ROS levels and enabling NK cell anti-tumor cytotoxicity together with activation of anti-tumor response resulting in improved clinical outcome of advanced cancer patients (60, 209-215).

Arginase inhibitors are promising pharmacological agents to treat NK suppression (216) and blocking Argl activity in the TME could shift the balance of $\mathrm{L}$-arginine metabolism, favoring $\mathrm{T}$ cell and NK cell proliferation (217). In murine studies, injection of the arginase inhibitor hydroxy-nor-arginine (nor-NOHA) or $\mathrm{N} \omega$-hydroxy-arginine (NOHA) or genetic disruption of Arg1 in the myeloid compartment resulted in reduced tumor growth (218-220). In murine syngeneic tumor model, CB-1158, a potent and orally-bioavailable small-molecule inhibitor of arginase, shifted the tumor immune landscape blunting myeloid cellmediated immune evasion, increasing tumor-infiltrating $\mathrm{CD}^{+} \mathrm{T}$ cells and NK cells (182). In colorectal cancer patients undergoing tumor resection, supplementation of arginine prior to surgery resulted in an increase in $\mathrm{CD} 16^{+}$and $\mathrm{CD} 56^{+} \mathrm{NK}$ cells infiltrating the tumors (221).

Cyclooxygenase (COX)-2 inhibitors, celecoxib, or nimesulide have been successfully tested in preclinical models for preventing local and systemic expansion of all MDSC subtypes resulting in reduced tumor progression (222-225). On the hand, COX2 inhibitors induce the expression of NKG2D ligands in cancer cells and increase their susceptibility to NK cell-mediated cell death $(226,227)$ together with blocking multiple angiogenic and lymphangiogenic such as VEGF-A, VEGF-C/D) (228).

ROS production is one the mechanisms employed by MDSC for immunosuppression $(226,229)$. In this context, phytochemicals, via their antioxidant property, can activate Nrf2 
pathway, that is considered tumor-protective, in particular in the early stages of tumorigenesis. The synthetic triterpenoid C-28 methyl ester of 2-cyano-3,12-dioxooleana-1,9,-dien-28oic acid (CDDO-Me, also referred to as bardoxolone methyl, RTA402, TP-155, and NSC713200) is a potent Nrf2 activator and has been found to reduce MDSC production of ROS and tumor growth in mouse tumor models (230) and showed a promising anticancer effect in a phase I trial (231). In addition, Nrf2 upregulation, regulates early anti-cancer immune responses and induces the cytokine interleukin-17D (IL-17D), that is overexpressed in highly immunogenic tumor cells and play an important role in immune rejection mediated by NK cells $(232,233)$. Inducing IL-17D using Nrf2 agonists boost innate immunity and NK recruitment leading to tumorregression $(234,235)$. An increasing number of recent reports suggest the abilities of the antidiabetic drugs, phenformin, and metformin to selectively reduce the number-MDSCs and the immunosuppressive functions of MDSC in the TME, through the activation of AMPK (236-240). Phenformin and metformin were able to inhibit immune suppressive activities MDSCs and potentiated the anti-tumor activity of PD-1 blockade immunotherapy $(236,240,241)$.

In addition, metformin and phenformin have been widely investigated for their properties in inhibiting angiogenesis and blocking tumor progression (242-244). Several scientific evidences revealed that metformin exerts also strong immunomodulatory effects and contributes to the enhancement of cytotoxic T lymphocyte (245-247) Polyinosinic-polycytidylic acid [Poly (I: C) an agonist for pattern-recognition receptors (PRRs), toll-like receptor 3 (TLR3) has been reported to decrease MDSC frequencies in BM, blood, and tumor and abrogate their immunosuppressive, concomitant with an NK cell activation (248-251).

\section{CONCLUSIONS}

MDSC are major players in the immunosuppressive scenario in cancer, thanks to their phenotype heterogeneity and

\section{REFERENCES}

1. Balkwill FR, Capasso M, Hagemann T. The tumor microenvironment at a glance. J Cell Sci. (2012) 125 (Pt 23):5591-6. doi: 10.1242/jcs.1 16392

2. Binnewies M, Roberts EW, Kersten K, Chan V, Fearon DF, Merad M, et al. Understanding the tumor immune microenvironment (TIME) for effective therapy. Nat Med. (2018) 24:541-50. doi: 10.1038/s41591-0180014-x

3. Noonan DM, De Lerma Barbaro A, Vannini N, Mortara L, Albini A. Inflammation, inflammatory cells and angiogenesis: decisions and indecisions. Cancer Metastasis Rev. (2008) 27:31-40. doi: 10.1007/s10555-007-9108-5

4. Albini A, Bruno A, Noonan DM, Mortara L. Contribution to tumor angiogenesis from innate immune cells within the tumor microenvironment: implications for immunotherapy. Front Immunol. (2018) 9:527. doi: 10.3389/fimmu.2018.00527

5. Granot Z, Fridlender ZG. Plasticity beyond cancer cells and the "immunosuppressive switch". Cancer Res. (2015) 75:4441-5. doi: 10.1158/0008-5472.CAN-15-1502 critical interaction with several innate immune cells, thus representing a crucial target in oncology. Here we reviewed the interactions of MDSCs with NK cells. The contribution of key cytokines, chemokines and mediators active in this process have been discussed.

We also described the contribution of MDSC on angiogenesis directly or indirectly through interactions with $\mathrm{NK}$ and immunosuppressive activities. A parallel of the cancer associated to the decidual counterpart of these cells is discussed, as to propose an onco-fetal origin of the polarization.

In addition to the well-characterized role in immunosuppression, MDSC possess potent pro-angiogenic capabilities, and actively participate in the resistance to VEGFtargeted therapy. Considering the crucial role of MDSC in inducing and regulating a permissive immune TME, in directly contributing to angiogenesis and tumor invasion, several strategies to therapeutically target these cells are currently being tested in clinic. Several pre-clinical studies show that targeting MDSC through multiple approaches helps to increases NK cells tumor activity augment the efficacy of anti-angiogenic therapy.

A better understanding of the link between MDSCNK immunosuppressive network in TME and their influence on angiogenesis can be translated to new therapeutic targets.

\section{AUTHOR CONTRIBUTIONS}

$\mathrm{DN}$ and AA: design, review and revision of the manuscript, and revision of the figures; LM: writing, review, and revision of the manuscript; DB: writing, review, and preparing figures; $\mathrm{AB}$ : design, writing, review, and revision of the manuscript and drafting of the figures.

\section{FUNDING}

DB is supported by a postdoctoral fellowship by the Fondazione Umberto Veronesi (FUV).

6. Holzel M, Bovier A, Tuting T. Plasticity of tumour and immune cells: a source of heterogeneity and a cause for therapy resistance? Nat Rev Cancer. (2013) 13:365-76. doi: 10.1038/nrc3498

7. Ostrand-Rosenberg S, Sinha P, Beury DW, Clements VK. Cross-talk between myeloid-derived suppressor cells (MDSC), macrophages, and dendritic cells enhances tumor-induced immune suppression. Semin Cancer Biol. (2012) 22:275-81. doi: 10.1016/j.semcancer.2012.01.011

8. Sinha P, Clements VK, Bunt SK, Albelda SM, Ostrand-Rosenberg S. Crosstalk between myeloid-derived suppressor cells and macrophages subverts tumor immunity toward a type 2 response. J Immunol. (2007) 179:977-83. doi: 10.4049/jimmunol.179.2.977

9. Ben-Meir K, Twaik N, Baniyash M. Plasticity and biological diversity of myeloid derived suppressor cells. Curr Opin Immunol. (2018) 51:154-61. doi: 10.1016/j.coi.2018.03.015

10. Groth $\mathrm{C}, \mathrm{Hu} \mathrm{X}$, Weber R, Fleming V, Altevogt P, Utikal J, et al. Immunosuppression mediated by myeloid-derived suppressor cells (MDSCs) during tumour progression. Br J Cancer. (2019) 120:16-25. doi: 10.1038/s41416-018-0333-1

11. Umansky V, Blattner C, Fleming V, Hu X, Gebhardt C, Altevogt $\mathrm{P}$, et al. Myeloid-derived suppressor cells and tumor escape from 
immune surveillance. Semin Immunopathol. (2017) 39:295-305. doi: 10.1007/s00281-016-0597-6

12. Vivier E, Tomasello E, Baratin M, Walzer T, Ugolini S. Functions of natural killer cells. Nat Immunol. (2008) 9:503-10. doi: 10.1038/ni1582

13. Baginska J, Viry E, Paggetti J, Medves S, Berchem G, Moussay E, et al. The critical role of the tumor microenvironment in shaping natural killer cell-mediated anti-tumor immunity. Front Immunol. (2013) 4:490. doi: 10.3389/fimmu.2013.00490

14. Guillerey C, Huntington ND, Smyth MJ. Targeting natural killer cells in cancer immunotherapy. Nat Immunol. (2016) 17:1025-36. doi: $10.1038 /$ ni.3518

15. Waldhauer I, Steinle A. NK cells and cancer immunosurveillance. Oncogene. (2008) 27:5932-43. doi: 10.1038/onc.2008.267

16. Bosi A, Zanellato S, Bassani B, Albini A, Musco A, Cattoni M, et al. Natural killer cells from malignant pleural effusion are endowed with a deciduallike proangiogenic polarization. J Immunol Res. (2018) 2018:2438598. doi: $10.1155 / 2018 / 2438598$

17. Bruno A, Ferlazzo G, Albini A, Noonan DM. A think tank of TINK/TANKs: tumor-infiltrating/tumor-associated natural killer cells in tumor progression and angiogenesis. J Natl Cancer Inst. (2014) 106:dju200. doi: $10.1093 /$ jnci/dju200

18. Gotthardt D, Putz EM, Grundschober E, Prchal-Murphy M, Straka E, Kudweis P, et al. STAT5 is a key regulator in NK cells and acts as a molecular switch from tumor surveillance to tumor promotion. Cancer Discov. (2016) 6:414-29. doi: 10.1158/2159-8290.CD-15-0732

19. Levi I, Amsalem H, Nissan A, Darash-Yahana M, Peretz T, Mandelboim $\mathrm{O}$, et al. Characterization of tumor infiltrating natural killer cell subset. Oncotarget. (2015) 6:13835-43. doi: 10.18632/oncotarget.3453

20. Bronte V, Brandau S, Chen SH, Colombo MP, Frey AB, Greten $\mathrm{TF}$, et al. Recommendations for myeloid-derived suppressor cell nomenclature and characterization standards. Nat Commun. (2016) 7:12150. doi: $10.1038 /$ ncomms 12150

21. Budhwar S, Verma P, Verma R, Rai S, Singh K. The Yin and Yang of myeloid derived suppressor cells. Front Immunol. (2018) 9:2776. doi: 10.3389 /fimmu.2018.02776

22. Draghiciu O, Lubbers J, Nijman HW, Daemen T. Myeloid derived suppressor cells-An overview of combat strategies to increase immunotherapy efficacy. Oncoimmunology. (2015) 4:e954829. doi: 10.4161/21624011.2014.954829

23. Gabrilovich DI. Myeloid-derived suppressor cells. Cancer Immunol Res. (2017) 5:3-8. doi: 10.1158/2326-6066.CIR-16-0297

24. Sica A, Massarotti M. Myeloid suppressor cells in cancer and autoimmunity. J Autoimmun. (2017) 85:117-25. doi: 10.1016/j.jaut.2017.07.010

25. Spits H, Artis D, Colonna M, Diefenbach A, Di Santo JP, Eberl G, et al. Innate lymphoid cells-a proposal for uniform nomenclature. Nat Rev Immunol. (2013) 13:145-9. doi: 10.1038/nri3365

26. Vivier E, Artis D, Colonna M, Diefenbach A, Di Santo JP, Eberl G, et al. Innate lymphoid cells: 10 years on. Cell. (2018) 174:1054-66. doi: 10.1016/j.cell.2018.07.017

27. Chalifour A, Jeannin P, Gauchat JF, Blaecke A, Malissard M, N'Guyen T, et al. Direct bacterial protein PAMP recognition by human NK cells involves TLRs and triggers alpha-defensin production. Blood. (2004) 104:1778-83. doi: 10.1182/blood-2003-08-2820

28. Bouzani M, Ok M, McCormick A, Ebel F, Kurzai O, Morton CO, et al. Human NK cells display important antifungal activity against Aspergillus fumigatus, which is directly mediated by IFN-gamma release. J Immunol. (2011) 187:1369-76. doi: 10.4049/jimmunol.1003593

29. Li SS, Kyei SK, Timm-McCann M, Ogbomo H, Jones GJ, Shi M, et al. The NK receptor NKp30 mediates direct fungal recognition and killing and is diminished in NK cells from HIV-infected patients. Cell Host Microbe. (2013) 14:387-97. doi: 10.1016/j.chom.2013.09.007

30. Murphy WJ, Bennett M, Kumar V, Longo DL. Donor-type activated natural killer cells promote marrow engraftment and B cell development during allogeneic bone marrow transplantation. J Immunol. (1992) 148:2953-60.

31. Waggoner SN, Cornberg M, Selin LK, Welsh RM. Natural killer cells act as rheostats modulating antiviral T cells. Nature. (2011) 481:394-8. doi: $10.1038 /$ nature 10624

32. Kumar P, Thakar MS, Ouyang W, Malarkannan S. IL-22 from conventional NK cells is epithelial regenerative and inflammation protective during influenza infection. Mucosal Immunol. (2013) 6:69-82. doi: 10.1038/mi.2012.49

33. Carrega P, Bonaccorsi I, Di Carlo E, Morandi B, Paul P, Rizzello V, et al. CD56(bright)perforin(low) noncytotoxic human NK cells are abundant in both healthy and neoplastic solid tissues and recirculate to secondary lymphoid organs via afferent lymph. J Immunol. (2014) 192:3805-15. doi: 10.4049/jimmunol.1301889

34. Chiossone L, Dumas PY, Vienne M, Vivier E. Natural killer cells and other innate lymphoid cells in cancer. Nat Rev Immunol. (2018) 18:671-88. doi: 10.1038/s41577-018-0061-z

35. Lopez-Soto A, Gonzalez S, Smyth MJ, Galluzzi L. Control of Metastasis by NK Cells. Cancer Cell. (2017) 32:135-54. doi: 10.1016/j.ccell.2017.06.009

36. Parisi L, Bassani B, Tremolati M, Gini E, Farronato G, Bruno A. Natural killer cells in the orchestration of chronic inflammatory diseases. J Immunol Res. (2017) 2017:4218254. doi: 10.1155/2017/4218254

37. Wu J, Lanier LL. Natural killer cells and cancer. Adv Cancer Res. (2003) 90:127-56. doi: 10.1016/S0065-230X(03)90004-2

38. Zimmer J. Immunotherapy: natural killers take on cancer. Nature. (2014) 505:483. doi: $10.1038 / 505483 \mathrm{e}$

39. Bruno A, Focaccetti C, Pagani A, Imperatori AS, Spagnoletti M, Rotolo N, et al. The proangiogenic phenotype of natural killer cells in patients with non-small cell lung cancer. Neoplasia. (2013) 15:133-42. doi: $10.1593 /$ neo. 121758

40. Bruno A, Bassani B, D’Urso DG, Pitaku I, Cassinotti E, Pelosi G, et al. Angiogenin and the MMP9-TIMP2 axis are up-regulated in proangiogenic, decidual NK-like cells from patients with colorectal cancer. FASEB J. (2018) 32:5365-77. doi: 10.1096/fj.201701103R

41. Mandruzzato S, Brandau S, Britten CM, Bronte V, Damuzzo V, Gouttefangeas C, et al. Toward harmonized phenotyping of human myeloid-derived suppressor cells by flow cytometry: results from an interim study. Cancer Immunol Immunother. (2016) 65:161-9. doi: $10.1007 / \mathrm{s} 00262-015-1782-5$

42. Condamine T, Dominguez GA, Youn JI, Kossenkov AV, Mony S, AliceaTorres K, et al. Lectin-type oxidized LDL receptor-1 distinguishes population of human polymorphonuclear myeloid-derived suppressor cells in cancer patients. Sci Immunol. (2016) 1:aaf8943. doi: 10.1126/sciimmunol.aaf8943

43. Condamine T, Mastio J, Gabrilovich DI. Transcriptional regulation of myeloid-derived suppressor cells. J Leukoc Biol. (2015) 98:913-22. doi: 10.1189/jlb.4RI0515-204R

44. Kumar V, Patel S, Tcyganov E, Gabrilovich DI. The nature of myeloid-derived suppressor cells in the tumor microenvironment. Trends Immunol. (2016) 37:208-20. doi: 10.1016/j.it.2016.01.004

45. Messmer MN, Netherby CS, Banik D, Abrams SI. Tumor-induced myeloid dysfunction and its implications for cancer immunotherapy. Cancer Immunol Immunother. (2015) 64:1-13. doi: 10.1007/s00262-014-1639-3

46. Solito S, Marigo I, Pinton L, Damuzzo V, Mandruzzato S, Bronte V. Myeloidderived suppressor cell heterogeneity in human cancers. Ann N Y Acad Sci. (2014) 1319:47-65. doi: 10.1111/nyas. 12469

47. Zhang S, Ma X, Zhu C, Liu L, Wang G, Yuan X. The role of myeloid-derived suppressor cells in patients with solid tumors: a meta-analysis. PLOS ONE. (2016) 11:e0164514. doi: 10.1371/journal.pone.0164514

48. Gabrilovich DI, Velders MP, Sotomayor EM, Kast WM. Mechanism of immune dysfunction in cancer mediated by immature Gr- $1^{+}$myeloid cells. $J$ Immunol. (2001) 166:5398-406. doi: 10.4049/jimmunol.166.9.5398

49. Melani C, Chiodoni C, Forni G, Colombo MP. Myeloid cell expansion elicited by the progression of spontaneous mammary carcinomas in cerbB-2 transgenic BALB/c mice suppresses immune reactivity. Blood. (2003) 102:2138-45. doi: 10.1182/blood-2003-01-0190

50. Monu NR, Frey AB. Myeloid-derived suppressor cells and anti-tumor T cells: a complex relationship. Immunol Invest. (2012) 41:595-613. doi: $10.3109 / 08820139.2012 .673191$

51. Hoechst B, Gamrekelashvili J, Manns MP, Greten TF, Korangy F. Plasticity of human Th17 cells and iTregs is orchestrated by different subsets of myeloid cells. Blood. (2011) 117:6532-41. doi: 10.1182/blood-2010-11-317321

52. Elkabets M, Ribeiro VS, Dinarello CA, Ostrand-Rosenberg S, Di Santo JP, Apte RN, et al. IL-1beta regulates a novel myeloid-derived suppressor cell subset that impairs NK cell development and function. Eur J Immunol. (2010) 40:3347-57. doi: 10.1002/eji.201041037 
53. Liu C, Yu S, Kappes J, Wang J, Grizzle WE, Zinn KR, et al. Expansion of spleen myeloid suppressor cells represses NK cell cytotoxicity in tumor-bearing host. Blood. (2007) 109:4336-42. doi: 10.1182/blood-2006-09-046201

54. Movahedi K, Guilliams M, Van den Bossche J, Van den Bergh R, Gysemans $\mathrm{C}$, Beschin A, et al. Identification of discrete tumor-induced myeloid-derived suppressor cell subpopulations with distinct $\mathrm{T}$ cell-suppressive activity. Blood. (2008) 111:4233-44. doi: 10.1182/blood-2007-07-099226

55. Allan DS, Rybalov B, Awong G, Zuniga-Pflucker JC, Kopcow HD, Carlyle JR, et al. TGF-beta affects development and differentiation of human natural killer cell subsets. Eur J Immunol. (2010) 40:2289-95. doi: 10.1002/eji.200939910

56. Cerdeira AS, Rajakumar A, Royle CM, Lo A, Husain Z, Thadhani RI, et al. Conversion of peripheral blood NK cells to a decidual NK-like phenotype by a cocktail of defined factors. J Immunol. (2013) 190:3939-48. doi: 10.4049/jimmunol.1202582

57. Keskin DB, Allan DS, Rybalov B, Andzelm MM, Stern JN, Kopcow HD, et al. TGFbeta promotes conversion of $\mathrm{CD}^{+} 6^{+}$peripheral blood NK cells into $\mathrm{CD}^{-} 6^{-}$NK cells with similarities to decidual NK cells. Proc Natl Acad Sci USA. (2007) 104:3378-83. doi: 10.1073/pnas.0611098104

58. Kopcow HD, Allan DS, Chen X, Rybalov B, Andzelm MM, Ge B, et al. Human decidual NK cells form immature activating synapses and are not cytotoxic. Proc Natl Acad Sci USA. (2005) 102:15563-8. doi: 10.1073/pnas.0507835102

59. Li H, Han Y, Guo Q, Zhang M, Cao X. Cancer-expanded myeloid-derived suppressor cells induce anergy of NK cells through membrane-bound TGFbeta 1. J Immunol. (2009) 182:240-9. doi: 10.4049/jimmunol.182.1.240

60. Tai LH, Alkayyal AA, Leslie AL, Sahi S, Bennett S, Tanese de Souza $\mathrm{C}$, et al. Phosphodiesterase-5 inhibition reduces postoperative metastatic disease by targeting surgery-induced myeloid derived suppressor celldependent inhibition of Natural Killer cell cytotoxicity. Oncoimmunology. (2018) 7:e1431082. doi: 10.1080/2162402X.2018.1431082

61. Vaknin I, Blinder L, Wang L, Gazit R, Shapira E, Genina O, et al. A common pathway mediated through Toll-like receptors leads to Tand natural killer-cell immunosuppression. Blood. (2008) 111:1437-47. doi: 10.1182/blood-2007-07-100404

62. Hoechst B, Voigtlaender T, Ormandy L, Gamrekelashvili J, Zhao F, Wedemeyer $\mathrm{H}$, et al. Myeloid derived suppressor cells inhibit natural killer cells in patients with hepatocellular carcinoma via the NKp30 receptor. Hepatology. (2009) 50:799-807. doi: 10.1002/hep.23054

63. Nausch N, Galani IE, Schlecker E, Cerwenka A. Mononuclear myeloidderived "suppressor" cells express RAE-1 and activate natural killer cells. Blood. (2008) 112:4080-9. doi: 10.1182/blood-2008-03-143776

64. Sceneay J, Chow MT, Chen A, Halse HM, Wong CS, Andrews DM, et al. Primary tumor hypoxia recruits $\mathrm{CD} 11 \mathrm{~b}^{+} / \mathrm{Ly} 6 \mathrm{Cmed} / \mathrm{Ly}_{6 \mathrm{G}}{ }^{+}$immune suppressor cells and compromises NK cell cytotoxicity in the premetastatic niche. Cancer Res. (2012) 72:3906-11. doi: 10.1158/0008-5472.CAN-11-3873

65. Binsfeld M, Muller J, Lamour V, De Veirman K, De Raeve H, Bellahcene A, et al. Granulocytic myeloid-derived suppressor cells promote angiogenesis in the context of multiple myeloma. Oncotarget. (2016) 7:37931-43. doi: 10.18632/oncotarget.9270

66. Condamine T, Ramachandran I, Youn JI, Gabrilovich DI. Regulation of tumor metastasis by myeloid-derived suppressor cells. Annu Rev Med. (2015) 66:97-110. doi: 10.1146/annurev-med-051013-0 52304

67. Marvel D, Gabrilovich DI. Myeloid-derived suppressor cells in the tumor microenvironment: expect the unexpected. J Clin Invest. (2015) 125:3356-64. doi: 10.1172/JCI80005

68. Fortin C, Huang X, Yang Y. NK cell response to vaccinia virus is regulated by myeloid-derived suppressor cells. J Immunol. (2012) 189:18439. doi: 10.4049/jimmunol.1200584

69. Tai LH, de Souza CT, Belanger S, Ly L, Alkayyal AA, Zhang J, et al. Preventing postoperative metastatic disease by inhibiting surgeryinduced dysfunction in natural killer cells. Cancer Res. (2013) 73:97-107. doi: 10.1158/0008-5472.CAN-12-1993

70. Angka L, Khan ST, Kilgour MK, Xu R, Kennedy MA, Auer RC. Dysfunctional natural killer cells in the aftermath of cancer surgery. Int J Mol Sci. (2017) 18:18081787. doi: 10.3390/ijms18081787
71. Ihle JN. The Stat family in cytokine signaling. Curr Opin Cell Biol. (2001) 13:211-7. doi: 10.1016/S0955-0674(00)00199-X

72. Murray PJ. The JAK-STAT signaling pathway: input and output integration. J Immunol. (2007) 178:2623-9. doi: 10.4049/jimmunol.178.5.2623

73. O'Shea JJ, Gadina M, Kanno Y. Cytokine signaling: birth of a pathway. $J$ Immunol. (2011) 187:5475-8. doi: 10.4049/jimmunol.1102913

74. O'Shea JJ, Holland SM, Staudt LM. JAKs and STATs in immunity, immunodeficiency, and cancer. $N$ Engl J Med. (2013) 368:161-70. doi: 10.1056/NEJMra1202117

75. Johnson DE, O'Keefe RA, Grandis JR. Targeting the IL-6/JAK/STAT3 signalling axis in cancer. Nat Rev Clin Oncol. (2018) 15:234-48. doi: $10.1038 /$ nrclinonc. 2018.8

76. Thomas SJ, Snowden JA, Zeidler MP, Danson SJ. The role of JAK/STAT signalling in the pathogenesis, prognosis and treatment of solid tumours. $\mathrm{Br}$ J Cancer. (2015) 113:365-71. doi: 10.1038/bjc.2015.233

77. Yu H, Pardoll D, Jove R. STATs in cancer inflammation and immunity: a leading role for STAT3. Nat Rev Cancer. (2009) 9:798-809. doi: $10.1038 / \mathrm{nrc} 2734$

78. Sucher R, Kurz K, Weiss G, Margreiter R, Fuchs D, Brandacher G. IDOmediated tryptophan degradation in the pathogenesis of malignant tumor disease. Int J Tryptophan Res. (2010) 3:113-20. doi: 10.4137/IJTR.S4157

79. Yu J, Wang Y, Yan F, Zhang P, Li H, Zhao H, et al. Noncanonical NF-kappaB activation mediates STAT3-stimulated IDO upregulation in myeloid-derived suppressor cells in breast cancer. J Immunol. (2014) 193:2574-86. doi: 10.4049/jimmunol.1400833

80. Sun X, Sui Q, Zhang C, Tian Z, Zhang J. Targeting blockage of STAT3 in hepatocellular carcinoma cells augments NK cell functions via reverse hepatocellular carcinoma-induced immune suppression. Mol Cancer Ther. (2013) 12:2885-96. doi: 10.1158/1535-7163.MCT-12-1087

81. Sui Q, Zhang J, Sun X, Zhang C, Han Q, Tian Z. NK cells are the crucial antitumor mediators when STAT3-mediated immunosuppression is blocked in hepatocellular carcinoma. J Immunol. (2014) 193:2016-23. doi: 10.4049/jimmunol.1302389

82. Gotthardt D, Sexl V. STATs in NK-cells: the good, the bad, and the ugly. Front Immunol. (2016) 7:694. doi: 10.3389/fimmu.2016.00694

83. Gabrilovich DI, Ostrand-Rosenberg S, Bronte V. Coordinated regulation of myeloid cells by tumours. Nat Rev Immunol. (2012) 12:253-68. doi: $10.1038 /$ nri3175

84. Bierie B, Moses HL. Tumour microenvironment: TGFbeta: the molecular Jekyll and Hyde of cancer. Nat Rev Cancer. (2006) 6:506-20. doi: $10.1038 / \mathrm{nrc1} 926$

85. Lebrun JJ. The dual role of TGFbeta in human cancer: from tumor suppression to cancer metastasis. ISRN Mol Biol. (2012) 2012:381428. doi: $10.5402 / 2012 / 381428$

86. Massague J. TGFbeta in cancer. Cell. (2008) 134:215-30. doi: 10.1016/j.cell.2008.07.001

87. Molgora M, Bonavita E, Ponzetta A, Riva F, Barbagallo M, Jaillon S, et al. IL$1 \mathrm{R} 8$ is a checkpoint in NK cells regulating anti-tumour and anti-viral activity. Nature. (2017) 551:110-4. doi: 10.1038/nature24293

88. Fournie JJ, Poupot M. The pro-tumorigenic IL-33 involved in antitumor immunity: a Yin and Yang cytokine. Front Immunol. (2018) 9:2506. doi: 10.3389/fimmu.2018.02506

89. Shen JX, Liu J, Zhang GJ. Interleukin-33 in malignancies: friends or foes? Front Immunol. (2018) 9:3051. doi: 10.3389/fimmu.2018.03051

90. Choudhari SK, Chaudhary M, Bagde S, Gadbail AR, Joshi V. Nitric oxide and cancer: a review. World J Surg Oncol. (2013) 11:118. doi: 10.1186/1477-7819-11-118

91. Ying L, Hofseth LJ. An emerging role for endothelial nitric oxide synthase in chronic inflammation and cancer. Cancer Res. (2007) 67:1407-10. doi: 10.1158/0008-5472.CAN-06-2149

92. Stiff A, Trikha P, Mundy-Bosse B, McMichael E, Mace TA, Benner B, et al. Nitric oxide production by myeloid-derived suppressor cells plays a role in impairing Fc receptor-mediated natural killer cell function. Clin Cancer Res. (2018) 24:1891-904. doi: 10.1158/1078-0432.CCR-17-0691

93. Cifone MG, D’Alo S, Parroni R, Millimaggi D, Biordi L, Martinotti S, et al. Interleukin-2-activated rat natural killer cells express inducible nitric oxide synthase that contributes to cytotoxic function and interferon-gamma production. Blood. (1999) 93:3876-84. 
94. Furuke K, Burd PR, Horvath-Arcidiacono JA, Hori K, Mostowski H, Bloom ET. Human NK cells express endothelial nitric oxide synthase, and nitric oxide protects them from activation-induced cell death by regulating expression of TNF-alpha. J Immunol. (1999) 163:1473-80.

95. Harris SG, Padilla J, Koumas L, Ray D, Phipps RP. Prostaglandins as modulators of immunity. Trends Immunol. (2002) 23:144-50. doi: 10.1016/S1471-4906(01)02154-8

96. Maas R, Heller M. [Computed tomography of the skeletal system]. Rontgenpraxis. (1990) 43:293-300.

97. Wang D, Dubois RN. Eicosanoids and cancer. Nat Rev Cancer. (2010) 10:181-93. doi: 10.1038/nrc2809

98. Mao Y, Sarhan D, Steven A, Seliger B, Kiessling R, Lundqvist A. Inhibition of tumor-derived prostaglandin-e2 blocks the induction of myeloid-derived suppressor cells and recovers natural killer cell activity. Clin Cancer Res. (2014) 20:4096-106. doi: 10.1158/1078-0432.CCR-14-0635

99. Newson J, Motwani MP, Kendall AC, Nicolaou A, Muccioli GG, Alhouayek $\mathrm{M}$, et al. Inflammatory resolution triggers a prolonged phase of immune suppression through COX-1/mPGES-1-derived prostaglandin E2. Cell Rep. (2017) 20:3162-75. doi: 10.1016/j.celrep.2017.08.098

100. Lob S, Konigsrainer A, Rammensee HG, Opelz G, Terness P. Inhibitors of indoleamine-2,3-dioxygenase for cancer therapy: can we see the wood for the trees? Nat Rev Cancer. (2009) 9:445-52. doi: 10.1038/nrc2639

101. Munn DH, Mellor AL. IDO in the tumor microenvironment: inflammation, counter-regulation, and tolerance. Trends Immunol. (2016) 37:193-207. doi: 10.1016/j.it.2016.01.002

102. Fu B, Li X, Sun R, Tong X, Ling B, Tian Z, et al. Natural killer cells promote immune tolerance by regulating inflammatory $\mathrm{TH} 17$ cells at the human maternal-fetal interface. Proc Natl Acad Sci USA. (2013) 110:E23140. doi: $10.1073 /$ pnas. 1206322110

103. Godin-Ethier J, Pelletier S, Hanafi LA, Gannon PO, Forget MA, Routy JP, et al. Human activated T lymphocytes modulate IDO expression in tumors through Th1/Th2 balance. J Immunol. (2009) 183:7752-60. doi: 10.4049/jimmunol.0901004

104. Gostner JM, Becker K, Uberall F, Fuchs D. The potential of targeting indoleamine 2,3-dioxygenase for cancer treatment. Expert Opin Ther Targets. (2015) 19:605-15. doi: 10.1517/14728222.2014.995092

105. Hornyak L, Dobos N, Koncz G, Karanyi Z, Pall D, Szabo Z, et al. The role of indoleamine-2,3-dioxygenase in cancer development, diagnostics, and therapy. Front Immunol. (2018) 9:151. doi: 10.3389/fimmu.2018.00151

106. Yu J, Du W, Yan F, Wang Y, Li H, Cao S, et al. Myeloid-derived suppressor cells suppress antitumor immune responses through IDO expression and correlate with lymph node metastasis in patients with breast cancer. $J$ Immunol. (2013) 190:3783-97. doi: 10.4049/jimmunol.1201449

107. Zhang J, Han X, Hu X, Jin F, Gao Z, Yin L, et al. IDO1 impairs NK cell cytotoxicity by decreasing NKG2D/NKG2DLs via promoting miR-18a. Mol Immunol. (2018) 103:144-55. doi: 10.1016/j.molimm.2018.09.011

108. Della Chiesa M, Carlomagno S, Frumento G, Balsamo M, Cantoni $\mathrm{C}$, Conte $\mathrm{R}$, et al. The tryptophan catabolite L-kynurenine inhibits the surface expression of NKp46- and NKG2D-activating receptors and regulates NK-cell function. Blood. (2006) 108:4118-25. doi: 10.1182/blood-2006-03-006700

109. Allard B, Beavis PA, Darcy PK, Stagg J. Immunosuppressive activities of adenosine in cancer. Curr Opin Pharmacol. (2016) 29:7-16. doi: 10.1016/j.coph.2016.04.001

110. Antonioli L, Blandizzi C, Pacher P, Hasko G. Immunity, inflammation and cancer: a leading role for adenosine. Nat Rev Cancer. (2013) 13:842-57. doi: $10.1038 / \mathrm{nrc} 3613$

111. Chiu DK, Tse AP, Xu IM, Di Cui J, Lai RK, Li LL, et al. Hypoxia inducible factor HIF-1 promotes myeloid-derived suppressor cells accumulation through ENTPD2/CD39L1 in hepatocellular carcinoma. Nat Commun. (2017) 8:517. doi: 10.1038/s41467-017-00530-7

112. Ryzhov SV, Pickup MW, Chytil A, Gorska AE, Zhang Q, Owens P, et al. Role of TGF-beta signaling in generation of $\mathrm{CD} 39^{+} \mathrm{CD} 73^{+}$myeloid cells in tumors. J Immunol. (2014) 193:3155-64. doi: 10.4049/jimmunol.1400578

113. Raskovalova T, Lokshin A, Huang X, Jackson EK, Gorelik E. Adenosinemediated inhibition of cytotoxic activity and cytokine production by IL2/NKp46-activated NK cells: involvement of protein kinase A isozyme I (PKA I). Immunol Res. (2006) 36:91-9. doi: 10.1385/IR:36:1:91
114. Morandi F, Horenstein AL, Chillemi A, Quarona V, Chiesa S, Imperatori A, et al. CD56brightCD16- NK cells produce adenosine through a CD38-mediated pathway and act as regulatory cells inhibiting autologous CD4 ${ }^{+} \mathrm{T}$ cell proliferation. J Immunol. (2015) 195:965-72. doi: 10.4049/jimmunol.1500591

115. Cekic C, Day YJ, Sag D, Linden J. Myeloid expression of adenosine $\mathrm{A} 2 \mathrm{~A}$ receptor suppresses $\mathrm{T}$ and $\mathrm{NK}$ cell responses in the solid tumor microenvironment. Cancer Res. (2014) 74:7250-9. doi: 10.1158/0008-5472.CAN-13-3583

116. Blois SM, Klapp BF, Barrientos G. Decidualization and angiogenesis in early pregnancy: unravelling the functions of DC and NK cells. J Reprod Immunol. (2011) 88:86-92. doi: 10.1016/j.jri.2010.11.002

117. Hanna J, Goldman-Wohl D, Hamani Y, Avraham I, Greenfield C, NatansonYaron S, et al. Decidual NK cells regulate key developmental processes at the human fetal-maternal interface. Nat Med. (2006) 12:1065-74. doi: $10.1038 / \mathrm{nm} 1452$

118. Wallace AE, Fraser R, Gurung S, Goulwara SS, Whitley GS, Johnstone $\mathrm{AP}$, et al. Increased angiogenic factor secretion by decidual natural killer cells from pregnancies with high uterine artery resistance alters trophoblast function. Hum Reprod. (2014) 29:652-60. doi: 10.1093/humrep/deu017

119. Lash GE, Schiessl B, Kirkley M, Innes BA, Cooper A, Searle RF, et al. Expression of angiogenic growth factors by uterine natural killer cells during early pregnancy. J Leukoc Biol. (2006) 80:572-80. doi: 10.1189/jlb.0406250

120. Naruse K, Lash GE, Innes BA, Otun HA, Searle RF, Robson SC, et al. Localization of matrix metalloproteinase (MMP)-2, MMP-9 and tissue inhibitors for MMPs (TIMPs) in uterine natural killer cells in early human pregnancy. Hum Reprod. (2009) 24:553-61. doi: 10.1093/humrep/den408

121. Anacker J, Segerer SE, Hagemann C, Feix S, Kapp M, Bausch R, et al. Human decidua and invasive trophoblasts are rich sources of nearly all human matrix metalloproteinases. Mol Hum Reprod. (2011) 17:637-52. doi: $10.1093 / \mathrm{moleh} /$ gar033

122. Clark MM, Chazara O, Sobel EM, Gjessing HK, Magnus P, Moffett A, et al. Human birth weight and reproductive immunology: testing for interactions between maternal and offspring KIR and HLA-C genes. Hum Hered. (2016) 81:181-93. doi: 10.1159/000456033

123. Colucci F. The role of KIR and HLA interactions in pregnancy complications. Immunogenetics. (2017) 69:557-65. doi: 10.1007/s00251-017-1003-9

124. Cartwright JE, James-Allan L, Buckley RJ, Wallace AE. The role of decidual NK cells in pregnancies with impaired vascular remodelling. I Reprod Immunol. (2017) 119:81-4. doi: 10.1016/j.jri.2016.09.002

125. Kostlin N, Kugel H, Spring B, Leiber A, Marme A, Henes M, et al. Granulocytic myeloid derived suppressor cells expand in human pregnancy and modulate T-cell responses. Eur J Immunol. (2014) 44:2582-91. doi: 10.1002/eji.201344200

126. Nair RR, Sinha P, Khanna A, Singh K. Reduced myeloid-derived suppressor cells in the blood and endometrium is associated with early miscarriage. Am J Reprod Immunol. (2015) 73:479-86. doi: 10.1111/aji. 12351

127. Veglia F, Perego M, Gabrilovich D. Myeloid-derived suppressor cells coming of age. Nat Immunol. (2018) 19:108-19. doi: 10.1038/s41590-0170022-x

128. Papatriantafyllou M. Tumour immunology: MDSCs come at a cost. Nat Rev Immunol. (2011) 11:440-1. doi: 10.1038/nri3017

129. Wang Y, Liu Y, Shu C, Wan J, Shan Y, Zhi X, et al. Inhibition of pregnancyassociated granulocytic myeloid-derived suppressor cell expansion and arginase-1 production in preeclampsia. J Reprod Immunol. (2018) 127:48-54. doi: 10.1016/j.jri.2018.05.002

130. Safarzadeh E, Orangi M, Mohammadi H, Babaie F, Baradaran B. Myeloidderived suppressor cells: important contributors to tumor progression and metastasis. J Cell Physiol. (2018) 233:3024-36. doi: 10.1002/jcp.26075

131. Baniyash M. Myeloid-derived suppressor cells as intruders and targets: clinical implications in cancer therapy. Cancer Immunol Immunother. (2016) 65:857-67. doi: 10.1007/s00262-016-1849-y

132. Fleming $\mathrm{V}, \mathrm{Hu} \mathrm{X}$, Weber $\mathrm{R}$, Nagibin V, Groth $\mathrm{C}$, Altevogt $\mathrm{P}$, et al. Targeting myeloid-derived suppressor cells to bypass tumorinduced immunosuppression. Front Immunol. (2018) 9:398. doi: $10.3389 /$ fimmu. 2018.00398 
133. Yang L, DeBusk LM, Fukuda K, Fingleton B, Green-Jarvis B, Shyr Y, et al. Expansion of myeloid immune suppressor $\mathrm{Gr}^{+} \mathrm{CD}_{11} \mathrm{~b}^{+}$cells in tumorbearing host directly promotes tumor angiogenesis. Cancer Cell. (2004) 6:409-21. doi: 10.1016/j.ccr.2004.08.031

134. Kujawski M, Kortylewski M, Lee H, Herrmann A, Kay H, Yu H. Stat3 mediates myeloid cell-dependent tumor angiogenesis in mice. J Clin Invest. (2008) 118:3367-77. doi: 10.1172/JCI35213

135. Murdoch C, Muthana M, Coffelt SB, Lewis CE. The role of myeloid cells in the promotion of tumour angiogenesis. Nat Rev Cancer. (2008) 8:618-31. doi: $10.1038 / \mathrm{nrc} 2444$

136. Karakhanova S, Link J, Heinrich M, Shevchenko I, Yang Y, Hassenpflug $\mathrm{M}$, et al. Characterization of myeloid leukocytes and soluble mediators in pancreatic cancer: importance of myeloid-derived suppressor cells. Oncoimmunology. (2015) 4:e998519. doi: 10.1080/2162402X.2014.998519

137. Guedez L, Jensen-Taubman S, Bourboulia D, Kwityn CJ, Wei B, Caterina J, et al. TIMP-2 targets tumor-associated myeloid suppressor cells with effects in cancer immune dysfunction and angiogenesis. J Immunother. (2012) 35:502-12. doi: 10.1097/CJI.0b013e3182619c8e

138. Yang L, Huang J, Ren X, Gorska AE, Chytil A, Aakre M, et al. Abrogation of TGF beta signaling in mammary carcinomas recruits $\mathrm{Gr}-1^{+} \mathrm{CD} 11 \mathrm{~b}^{+}$ myeloid cells that promote metastasis. Cancer Cell. (2008) 13:23-35. doi: 10.1016/j.ccr.2007.12.004

139. Jacob A, Prekeris R. The regulation of MMP targeting to invadopodia during cancer metastasis. Front Cell Dev Biol. (2015) 3:4. doi: 10.3389/fcell.2015.00004

140. Sorrentino C, Miele L, Porta A, Pinto A, Morello S. Myeloid-derived suppressor cells contribute to $\mathrm{A} 2 \mathrm{~B}$ adenosine receptor-induced VEGF production and angiogenesis in a mouse melanoma model. Oncotarget. (2015) 6:27478-89. doi: 10.18632/oncotarget.4393

141. Iannone R, Miele L, Maiolino P, Pinto A, Morello S. Blockade of $\mathrm{A} 2 \mathrm{~b}$ adenosine receptor reduces tumor growth and immune suppression mediated by myeloid-derived suppressor cells in a mouse model of melanoma. Neoplasia. (2013) 15:1400-9. doi: 10.1593/neo.131748

142. Jayaraman P, Parikh F, Lopez-Rivera E, Hailemichael Y, Clark A, Ma G, et al. Tumor-expressed inducible nitric oxide synthase controls induction of functional myeloid-derived suppressor cells through modulation of vascular endothelial growth factor release. J Immunol. (2012) 188:5365-76. doi: 10.4049/jimmunol.1103553

143. Horikawa N, Abiko K, Matsumura N, Hamanishi J, Baba T, Yamaguchi $\mathrm{K}$, et al. Expression of vascular endothelial growth factor in ovarian cancer inhibits tumor immunity through the accumulation of myeloid-derived suppressor cells. Clin Cancer Res. (2017) 23:587-99. doi: 10.1158/1078-0432.CCR-16-0387

144. Voron T, Marcheteau E, Pernot S, Colussi O, Tartour E, Taieb J, et al. Control of the immune response by pro-angiogenic factors. Front Oncol. (2014) 4:70. doi: 10.3389/fonc.2014.00070

145. Yang J, Yan J, Liu B. Targeting VEGF/VEGFR to modulate antitumor immunity. Front Immunol. (2018) 9:978. doi: 10.3389/fimmu.2018.00978

146. Piao Y, Liang J, Holmes L, Zurita AJ, Henry V, Heymach JV, et al. Glioblastoma resistance to anti-VEGF therapy is associated with myeloid cell infiltration, stem cell accumulation, and a mesenchymal phenotype. Neuro Oncol. (2012) 14:1379-92. doi: 10.1093/neuonc/nos158

147. Hao Z, Sadek I. Sunitinib: the antiangiogenic effects and beyond. Onco Targets Ther. (2016) 9:5495-505. doi: 10.2147/OTT.S112242

148. Finke J, Ko J, Rini B, Rayman P, Ireland J, Cohen P. MDSC as a mechanism of tumor escape from sunitinib mediated anti-angiogenic therapy. Int Immunopharmacol. (2011) 11:856-61. doi: 10.1016/j.intimp.2011.01.030

149. Ferrara N. Role of myeloid cells in vascular endothelial growth factorindependent tumor angiogenesis. Curr Opin Hematol. (2010) 17:219-24. doi: 10.1097/MOH.0b013e3283386660

150. Chun E, Lavoie S, Michaud M, Gallini CA, Kim J, Soucy G, et al. CCL2 promotes colorectal carcinogenesis by enhancing polymorphonuclear myeloid-derived suppressor cell population and function. Cell Rep. (2015) 12:244-57. doi: 10.1016/j.celrep.2015.06.024

151. Obermajer N, Muthuswamy R, Odunsi K, Edwards RP, Kalinski P. PGE(2)-induced CXCL12 production and CXCR4 expression controls the accumulation of human MDSCs in ovarian cancer environment. Cancer Res. (2011) 71:7463-70. doi: 10.1158/0008-5472.CAN-11-2449
152. Alfaro C, Teijeira A, Onate C, Perez G, Sanmamed MF, Andueza MP, et al. Tumor-produced interleukin-8 attracts human myeloid-derived suppressor cells and elicits extrusion of neutrophil extracellular traps (NETs). Clin Cancer Res. (2016) 22:3924-36. doi: 10.1158/1078-0432.CCR-15-2463

153. Boelte KC, Gordy LE, Joyce S, Thompson MA, Yang L, Lin PC. Rgs2 mediates pro-angiogenic function of myeloid derived suppressor cells in the tumor microenvironment via upregulation of MCP-1. PLoS ONE. (2011) 6:e18534. doi: 10.1371/journal.pone.0018534

154. Wang Y, Zhang X, Yang L, Xue J, Hu G. Blockade of CCL2 enhances immunotherapeutic effect of anti-PD1 in lung cancer. J Bone Oncol. (2018) 11:27-32. doi: 10.1016/j.jbo.2018.01.002

155. Shojaei F, Wu X, Zhong C, Yu L, Liang XH, Yao J, et al. Bv8 regulates myeloid-cell-dependent tumour angiogenesis. Nature. (2007) 450:825-31. doi: 10.1038/nature06348

156. Shojaei F, Wu X, Qu X, Kowanetz M, Yu L, Tan M, et al. G-CSF-initiated myeloid cell mobilization and angiogenesis mediate tumor refractoriness to anti-VEGF therapy in mouse models. Proc Natl Acad Sci USA. (2009) 106:6742-7. doi: 10.1073/pnas.0902280106

157. Xin H, Lu R, Lee H, Zhang W, Zhang C, Deng J, et al. G-protein-coupled receptor agonist BV8/prokineticin-2 and STAT3 protein form a feed-forward loop in both normal and malignant myeloid cells. J Biol Chem. (2013) 288:13842-9. doi: 10.1074/jbc.M113.450049

158. Liu JF, Deng WW, Chen L, Li YC, Wu L, Ma SR, et al. Inhibition of JAK2/STAT3 reduces tumor-induced angiogenesis and myeloid-derived suppressor cells in head and neck cancer. Mol Carcinog. (2018) 57:429-39. doi: $10.1002 / \mathrm{mc} .22767$

159. Ahn GO, Seita J, Hong BJ, Kim YE, Bok S, Lee CJ, et al. Transcriptional activation of hypoxia-inducible factor-1 (HIF-1) in myeloid cells promotes angiogenesis through VEGF and S100A8. Proc Natl Acad Sci USA. (2014) 111:2698-703. doi: 10.1073/pnas.1320243111

160. Chiu DK, Xu IM, Lai RK, Tse AP, Wei LL, Koh HY, et al. Hypoxia induces myeloid-derived suppressor cell recruitment to hepatocellular carcinoma through chemokine (C-C motif) ligand 26. Hepatology. (2016) 64:797-813. doi: 10.1002/hep.28655

161. Kusmartsev S, Eruslanov E, Kubler H, Tseng T, Sakai Y, Su Z, et al. Oxidative stress regulates expression of VEGFR1 in myeloid cells: link to tumorinduced immune suppression in renal cell carcinoma. J Immunol. (2008) 181:346-53. doi: 10.4049/jimmunol.181.1.346

162. Wesolowski R, Markowitz J, Carson WE III. Myeloid derived suppressor cells-a new therapeutic target in the treatment of cancer. J Immunother Cancer. (2013) 1:10. doi: 10.1186/2051-1426-1-10

163. Alizadeh D, Larmonier N. Chemotherapeutic targeting of cancerinduced immunosuppressive cells. Cancer Res. (2014) 74:2663-8. doi: 10.1158/0008-5472.CAN-14-0301

164. Suzuki E, Kapoor V, Jassar AS, Kaiser LR, Albelda SM. Gemcitabine selectively eliminates splenic $\mathrm{Gr}-1^{+} / \mathrm{CD} 11 \mathrm{~b}^{+}$myeloid suppressor cells in tumor-bearing animals and enhances antitumor immune activity. Clin Cancer Res. (2005) 11:6713-21. doi: 10.1158/1078-0432.CCR-05-0883

165. Kuroda H, Mabuchi S, Kozasa K, Yokoi E, Matsumoto Y, Komura N, et al. PM01183 inhibits myeloid-derived suppressor cells in vitro and in vivo. Immunotherapy. (2017) 9:805-17. doi: 10.2217/imt-2017-0046

166. Mikyskova R, Indrova M, Vlkova V, Bieblova J, Simova J, Parackova Z et al. DNA demethylating agent 5-azacytidine inhibits myeloid-derived suppressor cells induced by tumor growth and cyclophosphamide treatment. J Leukoc Biol. (2014) 95:743-53. doi: 10.1189/jlb.0813435

167. Kodumudi KN, Woan K, Gilvary DL, Sahakian E, Wei S, Djeu JY. A novel chemoimmunomodulating property of docetaxel: suppression of myeloidderived suppressor cells in tumor bearers. Clin Cancer Res. (2010) 16:458394. doi: 10.1158/1078-0432.CCR-10-0733

168. Michels T, Shurin GV, Naiditch H, Sevko A, Umansky V, Shurin MR. Paclitaxel promotes differentiation of myeloid-derived suppressor cells into dendritic cells in vitro in a TLR4-independent manner. J Immunotoxicol. (2012) 9:292-300. doi: 10.3109/1547691X.2011.6 42418

169. Vincent J, Mignot G, Chalmin F, Ladoire S, Bruchard M, Chevriaux A, et al 5-Fluorouracil selectively kills tumor-associated myeloid-derived suppressor cells resulting in enhanced $\mathrm{T}$ cell-dependent antitumor immunity. Cancer Res. (2010) 70:3052-61. doi: 10.1158/0008-5472.CAN-09-3690 
170. Alizadeh D, Trad M, Hanke NT, Larmonier CB, Janikashvili N, Bonnotte B, et al. Doxorubicin eliminates myeloid-derived suppressor cells and enhances the efficacy of adoptive T-cell transfer in breast cancer. Cancer Res. (2014) 74:104-18. doi: 10.1158/0008-5472.CAN-13-1545

171. Gujar SA, Clements D, Dielschneider R, Helson E, Marcato P, Lee PW. Gemcitabine enhances the efficacy of reovirus-based oncotherapy through anti-tumour immunological mechanisms. Br J Cancer. (2014) 110:83-93. doi: 10.1038/bjc.2013.695

172. Le HK, Graham L, Cha E, Morales JK, Manjili MH, Bear HD. Gemcitabine directly inhibits myeloid derived suppressor cells in BALB/c mice bearing 4T1 mammary carcinoma and augments expansion of $\mathrm{T}$ cells from tumor-bearing mice. Int Immunopharmacol. (2009) 9:900-9. doi: 10.1016/j.intimp.2009.03.015

173. Cao G, Wang J, Zheng X, Wei H, Tian Z, Sun R. Tumor Therapeutics Work as Stress Inducers to Enhance Tumor Sensitivity to Natural Killer (NK) Cell Cytolysis by Up-regulating NKp30 Ligand B7-H6. J Biol Chem. (2015) 290:29964-73. doi: 10.1074/jbc.M115.674010

174. Shi L, Lin H, Li G, Sun Y, Shen J, Xu J, et al. Cisplatin enhances NK cells immunotherapy efficacy to suppress HCC progression via altering the androgen receptor (AR)-ULBP2 signals. Cancer Lett. (2016) 373:45-56. doi: 10.1016/j.canlet.2016.01.017

175. Ahmad SM, Haskell MJ, Raqib R, Stephensen CB. Markers of innate immune function are associated with vitamin a stores in men. J Nutr. (2009) 139:37785. doi: $10.3945 /$ jn. 108.100198

176. Du Four S, Maenhout SK, De Pierre K, Renmans D, Niclou SP, Thielemans $\mathrm{K}$, et al. Axitinib increases the infiltration of immune cells and reduces the suppressive capacity of monocytic MDSCs in an intracranial mouse melanoma model. Oncoimmunology. (2015) 4:e998107. doi: 10.1080/2162402X.2014.998107

177. Guislain A, Gadiot J, Kaiser A, Jordanova ES, Broeks A, Sanders J, et al. Sunitinib pretreatment improves tumor-infiltrating lymphocyte expansion by reduction in intratumoral content of myeloid-derived suppressor cells in human renal cell carcinoma. Cancer Immunol Immunother. (2015) 64:124150. doi: 10.1007/s00262-015-1735-Z

178. Ko JS, Zea AH, Rini BI, Ireland JL, Elson P, Cohen P, et al. Sunitinib mediates reversal of myeloid-derived suppressor cell accumulation in renal cell carcinoma patients. Clin Cancer Res. (2009) 15:2148-57. doi: 10.1158/1078-0432.CCR-08-1332

179. Ozao-Choy J, Ma G, Kao J, Wang GX, Meseck M, Sung M, et al. The novel role of tyrosine kinase inhibitor in the reversal of immune suppression and modulation of tumor microenvironment for immune-based cancer therapies. Cancer Res. (2009) 69:2514-22. doi: 10.1158/0008-5472.CAN-08-4709

180. Stiff A, Trikha P, Wesolowski R, Kendra K, Hsu V, Uppati S, et al. Myeloidderived suppressor cells express Bruton's tyrosine kinase and can be depleted in tumor-bearing hosts by ibrutinib treatment. Cancer Res. (2016) 76:212536. doi: 10.1158/0008-5472.CAN-15-1490

181. Xin H, Zhang C, Herrmann A, Du Y, Figlin R, Yu H. Sunitinib inhibition of Stat3 induces renal cell carcinoma tumor cell apoptosis and reduces immunosuppressive cells. Cancer Res. (2009) 69:2506-13. doi: 10.1158/0008-5472.CAN-08-4323

182. Steggerda SM, Bennett MK, Chen J, Emberley E, Huang T, Janes JR, et al. Inhibition of arginase by CB-1158 blocks myeloid cell-mediated immune suppression in the tumor microenvironment. J Immunother Cancer. (2017) 5:101. doi: 10.1186/s40425-017-0308-4

183. Huang Y, Wang Y, Li Y, Guo K, He Y. Role of sorafenib and sunitinib in the induction of expressions of NKG2D ligands in nasopharyngeal carcinoma with high expression of ABCG2. J Cancer Res Clin Oncol. (2011) 137:829-37. doi: 10.1007/s00432-010-0944-2

184. Xian P, Li Y, Zhou H, Luo H, Liu N, Dai JY. [Effect of Sunitinib therapy on immune function of patients with advanced renal cell carcinoma]. Zhonghua Wai Ke Za Zhi. (2016) 54:741-5. doi: 10.3760/cma.j.issn.0529-5815.2016.10.004

185. Wiers KM, Lathers DM, Wright MA, Young MR. Vitamin D3 treatment to diminish the levels of immune suppressive $\mathrm{CD} 34^{+}$cells increases the effectiveness of adoptive immunotherapy. J Immunother. (2000) 23:115-24. doi: 10.1097/00002371-200001000-00014
186. Lathers DM, Clark JI, Achille NJ, Young MR. Phase 1B study to improve immune responses in head and neck cancer patients using escalating doses of 25-hydroxyvitamin D3. Cancer Immunol Immunother. (2004) 53:422-30. doi: 10.1007/s00262-003-0459-7

187. Mortara L, Gariboldi MB, Bosi A, Bregni M, Pinotti G, Guasti L, et al. Vitamin D deficiency has a negative impact on cetuximab-mediated cellular cytotoxicity against human colon carcinoma cells. Target Oncol. (2018) 13:657-65. doi: 10.1007/s11523-018-0586-x

188. Merrigan SL, Kennedy BN. Vitamin D receptor agonists regulate ocular developmental angiogenesis and modulate expression of dre-miR-21 and VEGF. Br J Pharmacol. (2017) 174:2636-51. doi: 10.1111/bph.13875

189. Lee GY, Han SN. The role of vitamin E in immunity. Nutrients. (2018) 10:10111614. doi: 10.3390/nu10111614

190. Nefedova Y, Fishman M, Sherman S, Wang X, Beg AA, Gabrilovich DI. Mechanism of all-trans retinoic acid effect on tumor-associated myeloid-derived suppressor cells. Cancer Res. (2007) 67:11021-8. doi: 10.1158/0008-5472.CAN-07-2593

191. Mirza N, Fishman M, Fricke I, Dunn M, Neuger AM, Frost TJ, et al. All-trans-retinoic acid improves differentiation of myeloid cells and immune response in cancer patients. Cancer Res. (2006) 66:9299-307. doi: 10.1158/0008-5472.CAN-06-1690

192. Li Y, Wongsiriroj N, Blaner WS. The multifaceted nature of retinoid transport and metabolism. Hepatobiliary Surg Nutr. (2014) 3:126-39. doi: 10.3978/j.issn.2304-3881.2014.05.04

193. Iclozan C, Antonia S, Chiappori A, Chen DT, Gabrilovich D. Therapeutic regulation of myeloid-derived suppressor cells and immune response to cancer vaccine in patients with extensive stage small cell lung cancer. Cancer Immunol Immunother. (2013) 62:909-18. doi: 10.1007/s00262-013-1396-8

194. Bauer R, Udonta F, Wroblewski M, Ben-Batalla I, Santos IM, Taverna F, et al. Blockade of myeloid-derived suppressor cell expansion with all-trans retinoic acid increases the efficacy of antiangiogenic therapy. Cancer Res. (2018) 78:3220-32. doi: 10.1158/0008-5472.CAN-17-3415

195. Li N, Lu Y, Li D, Zheng X, Lian J, Li S, et al. All-trans retinoic acid suppresses the angiopoietin-Tie2 pathway and inhibits angiogenesis and metastasis in esophageal squamous cell carcinoma. PLoS ONE. (2017) 12:e0174555. doi: 10.1371/journal.pone. 0174555

196. Jinushi M, Takehara T, Tatsumi T, Kanto T, Groh V, Spies T, et al. Expression and role of MICA and MICB in human hepatocellular carcinomas and their regulation by retinoic acid. Int J Cancer. (2003) 104:354-61. doi: 10.1002/ijc.10966

197. Li A, He M, Wang H, Qiao B, Chen P, Gu H, et al. All-trans retinoic acid negatively regulates cytotoxic activities of nature killer cell line 92 . Biochem Biophys Res Commun. (2007) 352:42-7. doi: 10.1016/j.bbrc.2006.10.132

198. Konjevic G, Mirjacic-Martinovic K, Vuletic A, Babovic N. In vitro increased natural killer cell activity of metastatic melanoma patients with interferon-alpha alone as opposed to its combination with 13-cis retinoic acid is associated with modulation of NKG2D and CD161 activating receptor expression. J BUON. (2012) 17:761-9.

199. Blattner C, Fleming V, Weber R, Himmelhan B, Altevogt P, Gebhardt $\mathrm{C}$, et al. $\mathrm{CCR}^{+}$myeloid-derived suppressor cells are enriched and activated in melanoma lesions. Cancer Res. (2018) 78:157-67. doi: 10.1158/0008-5472.CAN-17-0348

200. Lin L, Deangelis S, Foust E, Fuchs J, Li C, Li PK, et al. A novel small molecule inhibits STAT3 phosphorylation and DNA binding activity and exhibits potent growth suppressive activity in human cancer cells. Mol Cancer. (2010) 9:217. doi: 10.1186/1476-4598-9-217

201. Bill MA, Fuchs JR, Li C, Yui J, Bakan C, Benson DM Jr., et al. The small molecule curcumin analog FLLL32 induces apoptosis in melanoma cells via STAT3 inhibition and retains the cellular response to cytokines with anti-tumor activity. Mol Cancer. (2010) 9:165. doi: 10.1186/1476-4598-9-165

202. $\mathrm{Lu} \mathrm{P}, \mathrm{Yu} \mathrm{B}, \mathrm{Xu}$ J. Cucurbitacin B regulates immature myeloid cell differentiation and enhances antitumor immunity in patients with lung cancer. Cancer Biother Radiopharm. (2012) 27:495-503. doi: $10.1089 /$ cbr.2012.1219

203. Kortylewski M, Moreira D. Myeloid cells as a target for oligonucleotide therapeutics: turning obstacles into opportunities. Cancer Immunol Immunother. (2017) 66:979-88. doi: 10.1007/s00262-017-1966-2 
204. Spinetti T, Spagnuolo L, Mottas I, Secondini C, Treinies M, Ruegg C, et al. TLR7-based cancer immunotherapy decreases intratumoral myeloidderived suppressor cells and blocks their immunosuppressive function. Oncoimmunology. (2016) 5:e1230578. doi: 10.1080/2162402X.2016.1230578

205. Zhang Q, Hossain DM, Duttagupta P, Moreira D, Zhao X, Won H, et al. Serum-resistant CpG-STAT3 decoy for targeting survival and immune checkpoint signaling in acute myeloid leukemia. Blood. (2016) 127:1687-700. doi: 10.1182/blood-2015-08-665604

206. Orillion A, Hashimoto A, Damayanti N, Shen L, Adelaiye-Ogala R, Arisa S, et al. Entinostat neutralizes myeloid-derived suppressor cells and enhances the antitumor effect of PD-1 inhibition in murine models of lung and renal cell carcinoma. Clin Cancer Res. (2017) 23:5187-201. doi: 10.1158/1078-0432.CCR-17-0741

207. Kim K, Skora AD, Li Z, Liu Q, Tam AJ, Blosser RL, et al. Eradication of metastatic mouse cancers resistant to immune checkpoint blockade by suppression of myeloid-derived cells. Proc Natl Acad Sci USA. (2014) 111:11774-9. doi: 10.1073/pnas.1410626111

208. Hicks KC, Fantini M, Donahue RN, Schwab A, Knudson KM, Tritsch SR, et al. Epigenetic priming of both tumor and NK cells augments antibodydependent cellular cytotoxicity elicited by the anti-PD-L1 antibody avelumab against multiple carcinoma cell types. Oncoimmunology. (2018) 7:e1466018. doi: 10.1080/2162402X.2018.1466018

209. Serafini P, Meckel K, Kelso M, Noonan K, Califano J, Koch W, et al. Phosphodiesterase-5 inhibition augments endogenous antitumor immunity by reducing myeloid-derived suppressor cell function. J Exp Med. (2006) 203:2691-702. doi: 10.1084/jem.20061104

210. Meyer C, Sevko A, Ramacher M, Bazhin AV, Falk CS, Osen W, et al. Chronic inflammation promotes myeloid-derived suppressor cell activation blocking antitumor immunity in transgenic mouse melanoma model. Proc Natl Acad Sci USA. (2011) 108:17111-6. doi: 10.1073/pnas.1108121108

211. Lin S, Wang J, Wang L, Wen J, Guo Y, Qiao W, et al. Phosphodiesterase5 inhibition suppresses colonic inflammation-induced tumorigenesis via blocking the recruitment of MDSC. Am J Cancer Res. (2017) 7:41-52.

212. Califano JA, Khan Z, Noonan KA, Rudraraju L, Zhang Z, Wang H, et al. Tadalafil augments tumor specific immunity in patients with head and neck squamous cell carcinoma. Clin Cancer Res. (2015) 21:30-8. doi: 10.1158/1078-0432.CCR-14-1716

213. Weed DT, Vella JL, Reis IM, De la Fuente AC, Gomez C, Sargi Z, et al. Tadalafil reduces myeloid-derived suppressor cells and regulatory $\mathrm{T}$ cells and promotes tumor immunity in patients with head and neck squamous cell carcinoma. Clin Cancer Res. (2015) 21:39-48. doi: 10.1158/1078-0432.CCR-14-1711

214. Hassel JC, Jiang H, Bender C, Winkler J, Sevko A, Shevchenko I, et al. Tadalafil has biologic activity in human melanoma. Results of a pilot trial with Tadalafil in patients with metastatic Melanoma (TaMe). Oncoimmunology. (2017) 6:e1326440. doi: 10.1080/2162402X.2017.1326440

215. Hamilton TK, Hu N, Kolomitro K, Bell EN, Maurice DH, Graham $\mathrm{CH}$, et al. Potential therapeutic applications of phosphodiesterase inhibition in prostate cancer. World J Urol. (2013) 31:325-30. doi: 10.1007/s00345-012-0848-7

216. Oberlies J, Watzl C, Giese T, Luckner C, Kropf P, Muller I, et al. Regulation of NK cell function by human granulocyte arginase. J Immunol. (2009) 182:5259-67. doi: 10.4049/jimmunol.0803523

217. Rodriguez PC, Ochoa AC, Al-Khami AA. Arginine metabolism in myeloid cells shapes innate and adaptive immunity. Front Immunol. (2017) 8:93. doi: 10.3389/fimmu.2017.00093

218. Rodriguez PC, Quiceno DG, Zabaleta J, Ortiz B, Zea AH, Piazuelo MB, et al. Arginase I production in the tumor microenvironment by mature myeloid cells inhibits T-cell receptor expression and antigen-specific T-cell responses. Cancer Res. (2004) 64:5839-49. doi: 10.1158/0008-5472.CAN-04-0465

219. Colegio OR, Chu NQ, Szabo AL, Chu T, Rhebergen AM, Jairam V, et al. Functional polarization of tumour-associated macrophages by tumourderived lactic acid. Nature. (2014) 513:559-63. doi: 10.1038/nature13490

220. Rodriguez PC, Ochoa AC. Arginine regulation by myeloid derived suppressor cells and tolerance in cancer: mechanisms and therapeutic perspectives. Immunol Rev. (2008) 222:180-91. doi: 10.1111/j.1600-065X.2008.00608.x
221. Heys SD, Segar A, Payne S, Bruce DM, Kernohan N, Eremin O Dietary supplementation with L-arginine: modulation of tumour-infiltrating lymphocytes in patients with colorectal cancer. Br J Surg. (1997) 84:238-41. doi: $10.1002 /$ bjs. 1800840229

222. Veltman JD, Lambers ME, van Nimwegen M, Hendriks RW, Hoogsteden HC, Aerts JG, et al. COX-2 inhibition improves immunotherapy and is associated with decreased numbers of myeloid-derived suppressor cells in mesothelioma. Celecoxib influences MDSC function. BMC Cancer. (2010) 10:464. doi: 10.1186/1471-2407-10-464

223. Kuroda H, Mabuchi S, Yokoi E, Komura N, Kozasa K, Matsumoto Y, et al. Prostaglandin E2 produced by myeloid-derived suppressive cells induces cancer stem cells in uterine cervical cancer. Oncotarget. (2018) 9:36317-30. doi: 10.18632/oncotarget.26347

224. Kosaka A, Ohkuri T, Okada H. Combination of an agonistic anti-CD40 monoclonal antibody and the COX-2 inhibitor celecoxib induces anti-glioma effects by promotion of type-1 immunity in myeloid cells and T-cells. Cancer Immunol Immunother. (2014) 63:847-57. doi: 10.1007/s00262-014-1561-8

225. Iachininoto MG, Nuzzolo ER, Bonanno G, Mariotti A, Procoli A, Locatelli F, et al. Cyclooxygenase-2 (COX-2) inhibition constrains indoleamine 2,3dioxygenase 1 (IDO1) activity in acute myeloid leukaemia cells. Molecules. (2013) 18:10132-45. doi: 10.3390/molecules180910132

226. Corzo CA, Cotter MJ, Cheng P, Cheng F, Kusmartsev S, Sotomayor $\mathrm{E}$, et al. Mechanism regulating reactive oxygen species in tumorinduced myeloid-derived suppressor cells. J Immunol. (2009) 182:5693-701. doi: 10.4049/jimmunol.0900092

227. Kim SJ, Ha GH, Bae JH, Kim GR, Son CH, Park YS, et al. COX2- and endoplasmic reticulum stress-independent induction of ULBP1 and enhancement of sensitivity to NK cell-mediated cytotoxicity by celecoxib in colon cancer cells. Exp Cell Res. (2015) 330:451-9. doi: 10.1016/j.yexcr.2014.09.008

228. Majumder M, Nandi P, Omar A, Ugwuagbo KC, Lala PK. EP4 as a therapeutic target for aggressive human breast cancer. Int J Mol Sci. (2018) 19:19041019. doi: 10.3390/ijms19041019

229. Ohl K, Tenbrock K. Reactive oxygen species as regulators of MDSCmediated immune suppression. Front Immunol. (2018) 9:2499. doi: 10.3389/fimmu.2018.02499

230. Nagaraj S, Youn JI, Weber H, Iclozan C, Lu L, Cotter MJ, et al. Antiinflammatory triterpenoid blocks immune suppressive function of MDSCs and improves immune response in cancer. Clin Cancer Res. (2010) 16:181223. doi: 10.1158/1078-0432.CCR-09-3272

231. Wang YY, Yang YX, Zhe H, He ZX, Zhou SF. Bardoxolone methyl (CDDO-Me) as a therapeutic agent: an update on its pharmacokinetic and pharmacodynamic properties. Drug Des Devel Ther. (2014) 8:2075-88. doi: 10.2147/DDDT.S68872

232. O’Sullivan T, Saddawi-Konefka R, Gross E, Tran M, Mayfield SP, Ikeda $\mathrm{H}$, et al. Interleukin-17D mediates tumor rejection through recruitment of natural killer cells. Cell Rep. (2014) 7:989-98. doi: 10.1016/j.celrep.2014.03.073

233. Saddawi-Konefka R, O’Sullivan T, Gross ET, Washington A Jr., Bui JD. Tumor-expressed IL-17D recruits NK cells to reject tumors. Oncoimmunology. (2014) 3:e954853. doi: 10.4161/21624011.2014.9 54853

234. Saddawi-Konefka R, Seelige R, Gross ET, Levy E, Searles SC, Washington A Jr., et al. Nrf2 induces IL-17D to mediate tumor and virus surveillance. Cell Rep. (2016) 16:2348-58. doi: 10.1016/j.celrep.2016.07.075

235. Seelige R, Saddawi-Konefka R, Adams NM, Picarda G, Sun JC, Benedict $\mathrm{CA}$, et al. Interleukin-17D and $\mathrm{Nrf2}$ mediate initial innate immune cell recruitment and restrict MCMV infection. Sci Rep. (2018) 8:13670. doi: 10.1038/s41598-018-32011-2

236. Kim SH, Li M, Trousil S, Zhang Y, Pasca di Magliano M, Swanson KD, et al. Phenformin inhibits myeloid-derived suppressor cells and enhances the antitumor activity of PD-1 blockade in melanoma. J Invest Dermatol. (2017) 137:1740-8. doi: 10.1016/j.jid.2017.03.033

237. Qin G, Lian J, Huang L, Zhao Q, Liu S, Zhang Z, et al. Metformin blocks myeloid-derived suppressor cell accumulation through AMPK-DACH1-CXCL1 axis. Oncoimmunology. (2018) 7:e1442167. doi: 10.1080/2162402X.2018.1442167 
238. Uehara T, Eikawa S, Nishida M, Kunisada Y, Yoshida A, Fujiwara $\mathrm{T}$, et al. Metformin induces $\mathrm{CD}_{11} \mathrm{~b}^{+}$cell-mediated growth inhibition of an osteosarcoma: implications for metabolic reprogramming of myeloid cells and antitumor effects. Int Immunol. (2018) 31:187-98. doi: 10.1093/intimm/dxy079

239. de Mey S, Jiang H, Wang H, Engels B, Gevaert T, Dufait I, et al. Potential of memory $\mathrm{T}$ cells in bridging preoperative chemoradiation and immunotherapy in rectal cancer. Radiother Oncol. (2018) 127:361-9. doi: 10.1016/j.radonc.2018.04.003

240. Li L, Wang L, Li J, Fan Z, Yang L, Zhang Z, et al. Metformin-induced reduction of CD39 and CD73 blocks myeloid-derived suppressor cell activity in patients with ovarian cancer. Cancer Res. (2018) 78:1779-91. doi: 10.1158/0008-5472.CAN-17-2460

241. Scharping NE, Menk AV, Whetstone RD, Zeng X, Delgoffe GM. Efficacy of PD-1 blockade is potentiated by metformin-induced reduction of tumor hypoxia. Cancer Immunol Res. (2017) 5:9-16. doi: 10.1158/2326-6066.CIR-16-0103

242. Kannarkatt J, Alkharabsheh O, Tokala H, Dimitrov NV. Metformin and angiogenesis in cancer-revisited. Oncology. (2016) 91:179-84. doi: $10.1159 / 000448175$

243. Orecchioni S, Reggiani F, Talarico G, Mancuso P, Calleri A, Gregato G, et al. The biguanides metformin and phenformin inhibit angiogenesis, local and metastatic growth of breast cancer by targeting both neoplastic and microenvironment cells. Int $J$ Cancer. (2015) 136:E534-544. doi: 10.1002/ijc. 29193

244. Dallaglio K, Bruno A, Cantelmo AR, Esposito AI, Ruggiero L, Orecchioni S, et al. Paradoxic effects of metformin on endothelial cells and angiogenesis. Carcinogenesis. (2014) 35:1055-66. doi: 10.1093/carcin/bgu001

245. Cha JH, Yang WH, Xia W, Wei Y, Chan LC, Lim SO, et al. Metformin promotes antitumor immunity via endoplasmic-reticulumassociated degradation of PD-L1. Mol Cell. (2018) 71:606-20.e607. doi: 10.1016/j.molcel.2018.07.030

246. Pereira FV, Melo ACL, Low JS, de Castro IA, Braga TT, Almeida DC, et al. Metformin exerts antitumor activity via inductionof multiple death pathways in tumor cells and activation of a protective immune response. Oncotarget. (2018) 9:25808-25. doi: 10.18632/oncotarget.25380

247. Eikawa S, Nishida M, Mizukami S, Yamazaki C, Nakayama E, Udono H. Immune-mediated antitumor effect by type 2 diabetes drug, metformin. Proc Natl Acad Sci USA. (2015) 112:1809-14. doi: 10.1073/pnas.14176 36112

248. Ho V, Lim TS, Lee J, Steinberg J, Szmyd R, Tham M, et al. TLR3 agonist and Sorafenib combinatorial therapy promotes immune activation and controls hepatocellular carcinoma progression. Oncotarget. (2015) 6:2725266. doi: 10.18632/oncotarget.4583

249. Seya T, Shime H, Matsumoto M. Functional alteration of tumor-infiltrating myeloid cells in RNA adjuvant therapy. Anticancer Res. (2015) 35:4385-92.

250. Shime H, Kojima A, Maruyama A, Saito Y, Oshiumi H, Matsumoto M, et al. Myeloid-derived suppressor cells confer tumor-suppressive functions on natural killer cells via polyinosinic:polycytidylic acid treatment in mouse tumor models. J Innate Immun. (2014) 6:293-305. doi: 10.1159/0003 55126

251. Pang X, Song H, Zhang Q, Tu Z, Niu J. Hepatitis C virus regulates the production of monocytic myeloid-derived suppressor cells from peripheral blood mononuclear cells through PI3K pathway and autocrine signaling. Clin Immunol. (2016) 164:57-64. doi: 10.1016/j.clim.2016. 01.014

Conflict of Interest Statement: The authors declare that the research was conducted in the absence of any commercial or financial relationships that could be construed as a potential conflict of interest.

Copyright (C) 2019 Bruno, Mortara, Baci, Noonan and Albini. This is an open-access article distributed under the terms of the Creative Commons Attribution License (CC $B Y)$. The use, distribution or reproduction in other forums is permitted, provided the original author(s) and the copyright owner(s) are credited and that the original publication in this journal is cited, in accordance with accepted academic practice. No use, distribution or reproduction is permitted which does not comply with these terms. 